\title{
LA PARTICIPACIÓN DEL EXTRANEUS EN EL DELITO DE PREVARICACIÓN ADMINISTRATIVA: PRINCIPALES PROBLEMAS Y PROPUESTAS PARA SU SOLUCIÓN
}

\author{
Jordi Casas Hervilla ${ }^{1}$
}

Resumen: La actual configuración del elemento subjetivo en el delito de prevaricación administrativa, unida a su caracterización como delito especial propio, han venido generando importantes dificultades en el tratamiento punitivo de quienes de un modo deliberado han conducido a error a quienes gozan de la facultad para dictar resoluciones administrativas, provocando el dictado de resoluciones abiertamente contrarias a la legalidad.

Palabras clave: Delitos contra la administración pública, prevaricación, extraneus, accesoriedad.

Recibido: julio 2018. Aceptado: octubre 2018

1 Fiscal. Profesor asociado de Derecho Penal. ORCID ID 0000-0001-67388407.

Facultad de Derecho de la Universidad Autónoma de Barcelona. Edifici B2, Bellaterra, Carrer de la Vall Moronta, S/N, 08193 Cerdanyola del Vallès, Barcelona. Email: carrerajch@hotmail.com 


\section{THE PARTICIPATION OF AN EXTRANEUS IN THE OFFENCE OF ADMINISTRATIVE PREVARICATION: MAIN PROBLEMS AND PROPOSALS TO SOLVE THEM}

Summary: The current configuration of the subjective element in the offence of administrative prevarication, along with its characterisation as a special individual offence, have generated significant difficulties in the punitive treatment of those who have deliberately misled those with the power to issue administrative resolutions, thus causing resolutions that are openly against the law to be made.

Key words: Offences against public administration, prevarication, extraneus, legal accessory

\section{Consideraciones generales}

Nadie pone en duda que hoy día la corrupción resulta uno de los principales problemas que asola a nuestra sociedad. Se cuentan por centenares los artículos doctrinales y periodísticos que durante los últimos años han venido advirtiendo acerca de las nefastas consecuencias para el sistema democrático asociadas al fenómeno de la corrupción tales como la progresiva pérdida de la confianza de los ciudadanos en las instituciones, la progresiva politización de la justicia, la desestabilización de los mercados, etc... ${ }^{2}$

2 ASUA BATARRITA, A.: "La tutela penal del correcto funcionamiento de la Administración. Cuestiones político-criminales, criterios de interpretación y delimitación respecto a la potestad disciplinaria", en Varios autores, Delitos contra la Administración Pública, Bilbao, 1997, pp. 14 y ss.: "La década de los 90 ha sido escenario del desvelamiento, en numerosos países próximos y claramente en el nuestro, de escandalosos casos de enriquecimiento privado de políticos o altos funcionarios que se aprovecharon de su posición ventajosa derivada de su función y responsabilidades públicas. $\mathrm{Si}$ los casos descubiertos fueran una excepción aislada, no se explicaría las dimensiones de la preocupación actual. [...] La extensión de la intervención de los poderes públicos en la actividad económica, su papel de poderoso agente económico que contrata, distribuye, autoriza o concede servicios y prestaciones, inevitablemente conforma un escenario de riesgo para la aparición de presiones y connivencias ilícitas. En nuestro país, como es sabido, en abril del pasado año 1995 se creó la "Fiscalía Especial para la represión 
Resulta asimismo usual que aquellos que se han encargado de abordar el complicado análisis acerca de las causas subyacentes a la corrupción hayan venido poniendo el acento principalmente en la escasez de recursos para combatir a los corruptos.

Ciertamente la escasez de medios materiales y personales en la lucha contra la corrupción resulta manifiesta: el número de fiscales anticorrupción resulta a todas luces insuficiente (así a modo de ejemplo, sólo existen tres delegados de la Fiscalía Anticorrupción para toda Cataluña), la formación de jueces y fiscales se halla años luz del nivel deseable, la Administración de Justicia no cuenta con asesores -ni internos ni externos-que

de los Delitos Económicos relacionados con la Corrupción" y en ese mismo mes se aprobaron a la vez tres leyes dirigidas a extender la transparencia en la gestión pública: la ley de fondos reservados, la ley de contratos del Estado, y la ley de incompatibilidades de altos cargos".

Asimismo, DOLZ LAGO, M.J.: El delito de tráfico de influencias ante la lucha contra la corrupción política en España, Madrid, 2014, pp. 3 y ss: "Si bien desde un chauvinismo mal entendido nos podríamos "enorgullecer" que la corrupción política no es un mal exclusivamente propio, lo bien cierto es que estamos ante uno de los males endémicos o sistémicos que acechan especialmente a nuestra sociedad española desde tiempos inmemoriales, pudiéndose entroncar esta delincuencia en la llamada desde SUTHERLAND, "delincuencia de cuello blanco" - the White collar CRIMINALITY- o económica".

Vid. Manuel URQUIZA, J.: Corrupción Municipal. Por qué se produce y como evitarla, Córdoba, 2006, pp. 53 y ss.: "El creciente protagonismo de la vida municipal en el ámbito del Estado, a partir de que la Constitución de 1978 reconozca plenamente el poder de los Municipios para gestionar sus propios intereses ha hecho que un fenómeno tan voraz como la corrupción anide y germine en la esfera pública local, alcanzando a día de hoy, gran desarrollo. La corrupción global que se practica en los Ayuntamientos actualmente tiene un gran peso en nuestro país; aunque sea en términos relativos, [...] El fenómeno es más cercano al ciudadano; le afecta más porque incide en su vida de manera más directa. En términos generales, y con honrosas excepciones, se da todos los días en cualquier Ayuntamiento medianamente importante de España; con mayor o menor conciencia por parte de sus actores, con diferente intensidad, más o menos gravosamente, con desigual perversidad para el sistema democrático pero siempre de manera injusta e ilegítima, el fenómeno es global en el municipalismo español”. 
permitan suplir la ignorancia de jueces y fiscales, los grupos policiales dedicados a la lucha contra la corrupción son más bien escasos y a su vez se hallan faltos de conocimientos especiales en materias tales como el urbanismo, la contratación pública o la normativa administrativa, etc... ${ }^{3}$

Sin embargo, en mi opinión, la lucha contra el fenómeno de la corrupción no sólo encuentra obstáculos asociados a la falta de medios de todo orden, lejos de ello, cabe afirmar que los encargados de combatir la corrupción topan en algunas ocasiones - más en realidad de las que resulta lógico admitir sin desconfiar en el buen hacer del legislador- con dificultades derivadas de una deficiente, o cuanto menos controvertida, regulación penal. Claro ejemplo de ello resulta el tema que constituye objeto del presente artículo, pues no cabe sino afirmar que la actual regulación de la participación en los delitos especiales, singularmente los propios, resulta manifiestamente deficiente en tanto que

3 MenA ÁlvareZ, J.M.: De oficio Fiscal, Barcelona, 2010, pp. 191 y ss.:"La estructura clásica de las fiscalías no estaba concebida para hacer frente a las organizaciones criminales. Se partía, históricamente, del criterio según el cual cada fiscal, como cada juez, está preparado para abordar cualquier tipo de persecución penal de cualquier tipo de delito o delincuente. Pero esto, hoy, ya no es realista. En todas las disciplinas científicas, en todas las actividades profesionales, individuales o colegiadas, en todos los servicios públicos, van naciendo especializaciones a medida que la complejidad de las actividades y las necesidades lo requiera. Cuando Carlos Jiménez Villarejo se hizo cargo de la dirección de la Fiscalía de Cataluña, en 1987, pensamos en la necesidad de que algunos fiscales dispusieran de una particular preparación teórica, y sobre todo práctica, en materia de delincuencia organizada. Se ensayaron modelos más o menos eficaces, asumiendo el riesgo de los tropiezos, sin ningún respaldo jerárquico superior, logístico ni presupuestario. Se contó con la valía y entrega de algún fiscal excepcional. Se consiguió disponer de alguna persona experta en materias económicas y financieras para nuestro asesoramiento, ya que, como cualquiera puede suponer, como juristas, éramos unos ignorantes en las cuestiones técnicas específicas extrajurídicas de las complejas conductas cuya persecución intentábamos. Esta ignorancia no debe extrañar a nadie. [...] Cuando la fórmula funcionó se adoptó el modelo de la especialización, se crearon las fiscalías especiales correspondientes y empezó a perderse en el horizonte del retrovisor la vieja Fiscalía decimonónica". 
arroja en no pocas ocasiones soluciones jurídicas inaceptables por contrarias al sentido común, y por groseras para con los más elementales principios de justicia. ${ }^{4}$

\section{El delito de prevaricación como herramienta fundamental en la lucha contra la corrupción}

Sin ningún género de dudas la modalidad delictiva más aplicada en casos de corrupción resulta la prevaricación administrativa (sea en su modalidad genérica del art. $404 \mathrm{Cp}$, en el nombramiento de cargo público del art. $405 \mathrm{Cp}$, la medioambiental del art. $329 \mathrm{Cp}$, o la urbanística del art. $320 \mathrm{Cp}$ ).

El hecho de que esto sea así obedece en primer lugar a la circunstancia, fácilmente comprensible, de que por lo general la autoridad o funcionario corrompidos lo habrán sido con el fin de lograr el dictado de una resolución administrativa favorable a los intereses del corruptor. Así las cosas, lógico es pensar que quien se decide a sobornar a quien ostenta la condición de funcionario o cargo electo, usualmente obrará con la intención de obtener a cambio la recalificación de unos terrenos o el reconocimiento de un derecho patrimonial, o en definitiva cualquier otro beneficio, actuaciones que siempre precisarán del previo dictado de una o varias resoluciones administrativas.

Quien se decida a malversar caudales públicos, salvo supuestos absolutamente groseros, usualmente tratará de revestir su actuación de un barniz de legalidad mediante el dictado de resoluciones administrativas que amparen su ilícito proceder justificando las disposiciones patrimoniales efectuadas en su favor o en favor de un tercero, etc...

4 DOLZ LAGO, M.J.: El delito de tráfico..., ob. cit., p. 21: "La corrupción política es un cáncer contra el Estado de Derecho que lesiona no sólo el principio de legalidad en la actuación de los poderes públicos con sujeción a los criterios de objetividad e imparcialidad son también a valores éticos y morales, donde la política debe concebirse al servicio de los ciudadanos y no para servirse de los ciudadanos". 
En segundo lugar, pero no por ello menos importante, el que la prevaricación administrativa resulte uno de los tipos penales de mayor aplicación, en detrimento de otras modalidades típicas tales como el cohecho, el fraude a la Administración o el tráfico de influencias, o la revelación de secretos o información privilegiada o su uso, etc... resulta de la palmaria incapacidad de la Administración de Justicia para acreditar su ejecución. Existiendo notables dificultades no ya para obtener evidencias de su perpetración, sino tan siquiera meros indicios.

Adviértase que, salvo raras excepciones, la obtención de pruebas que permitan la atribución de estos delitos precisará de la interceptación de las telecomunicaciones de los implicados, o de la grabación de sus conversaciones, pues no debe olvidarse que se trata de delitos cuya ejecución habitualmente se desarrolla en la intimidad de los despachos profesionales o de los domicilios de los implicados, resultando como únicos "testigos" de lo sucedido los penalmente responsables.

Quien se decide, por poner un ejemplo, a sobornar a un alcalde con el fin de que conceda una licencia de obras ilegal, o bien para que tolere la ejecución de una obra sin licencia, se concertará con el cargo electo en la intimidad, sin miradas ajenas de ningún tipo, entregando las cantidades pactadas bien en metálico, bien mediante personas físicas o jurídicas interpuestas que dificulten la asociación entre corruptor y corrompido. De suerte que sólo los responsables del delito adquirirán conocimiento de lo realmente sucedido.

El sigilo y opacidad imperantes en la ejecución de los delitos de cohecho, tráfico de influencias, fraude a la administración pública e incluso malversación de caudales públicos, acarrean a su vez notables dificultades para que los órganos encargados de luchar contra la corrupción reciban la deseada notitia criminis $^{5}$.

5 PALOMAR OLMEDA, A./GARCÉS SANAGUSTÍN, M.: La gestión de los Fondos Públicos: Control y Responsabilidades, Navarra, 2013, pp. 50 y ss.: "Lo que no cabe negar es que la existencia se situaciones de corrupción 
Dificultad que a su vez se ve acrecentada por la inexistencia de un estatuto del confidente, pues no debe olvidarse que más allá de lo preceptuado por el art. 426 del Código penal no se prevén incentivos de tipo procesal ni tampoco económico que inviten a los implicados a redimir su ilícito proceder, por la inexistencia de órganos de persecución especializados en la detección de este tipo de ilícitos, por la ineficacia de los sistemas de fiscalización interna a causa de una configuración a todas luces inoperante, por la inexistencia de canales a través de los que vehicular la recepción de denuncias anónimas de un modo operativo, así como por la tolerancia de los representantes políticos, en la inmensa mayoría de ocasiones más preocupados por sus réditos políticos que por el esclarecimiento de lo realmente acaecido y la depuración de las oportunas responsabilidades criminales ${ }^{6}$.

en el ámbito público (que, curiosamente, en la mayor parte de los casos no implican a empleados públicos) proyectan, sin embargo, una imagen general del mal funcionamiento de las instituciones públicas y, sobre todo, de los instrumentos y formas de control públicos que, tan a menudo, resultan burlados por unos y otros generalizándose una sensación de que no son capaces de la detección precoz de las situaciones de corrupción".

6 GARCÍA ARÁN, M. (Directora): La delincuencia económica: Prevenir y sancionar, Valencia, 2014, pp. 99 y ss.: "En cuanto al control de legalidad interno, resulta obligado referirse a la progresiva limitación de la actuación de Secretarios e Interventores de las entidades locales, llamados a impulsar el control de legalidad ejercido internamente. La antigua figura de Secretario de Ayuntamiento ve limitado su ámbito de actuación desde la Ley 57/2003, de Modernización del Gobierno Local, pasando a ser sólo Secretario del Pleno y de las Comisiones. La Ley 7/1985 de 2 de abril, reguladora de las bases del régimen local sufre varias modificaciones, entre las que se cuenta la derogación de sus arts. 98 y 99 sobre selección de funcionarios con habilitación de carácter nacional (secretarios, interventores y tesoreros) por la Ley 7/2007 de 12 de abril del Estatuto Básico del Empleado Público. Tales cargos son de libre designación en municipios de más de 100.000 habitantes, capitales de provincia y capitales de comunidad autónoma (medida introducida en la Ley de Acompañamiento de los Presupuestos de 1992), con lo que en tales municipios, los llamados a controlar son elegidos a gusto del controlado".

Asimismo, QUINTERO OLIVARES, G.: "Urbanismo y corrupción en la Administración local", en MORILLAS CUEVA, L.: Urbanismo y corrupción política, Madrid, 2013, p. 43: "En teoría es la Administración la que 
La imposibilidad, pues, de obtener conocimiento de la noticia criminal de un modo ágil y eficaz, conduce a que por lo general la eventualidad de desarrollar medidas de investigación tales como la interceptación de las telecomunicaciones, los seguimientos y vigilancias policiales y la captación de la imagen y el sonido de los investigados resulte inviable, pues dicha posibilidad presupone que la investigación se desarrolle paralelamente a la ejecución del delito. De suerte que cuando la noticia criminal se reciba, tal y como sucede en la actualidad, varios años después de ejecutarse el delito, lo único que resultará posible será entonces analizar el expediente administrativo en cuestión al objeto de detectar las posibles irregularidades administrativas cometidas. Extremo éste que tan sólo permitirá en su caso atribuir a los implicados la ejecución de un delito de prevaricación, y sólo en muy contadas ocasiones de un delito de malversación.

Ciertamente, a nadie escapa que tras el dictado de una resolución arbitraria por quien ningún interés tiene en la misma, subyacerá por lo general alguna oscura causa que justifique el ilícito proceder de la autoridad o funcionario en cuestión, pues no resulta lógico pensar que quien ningún interés alberga en un asunto administrativo decida por iniciativa propia cometer una irregularidad de naturaleza criminal.

No obstante, a pesar de que tras buena parte de las prevaricaciones detectadas resulte en buena lógica posible inferir la entrega de una dádiva, o bien el ejercicio de presiones de distinta naturaleza, no debe olvidarse que ello no constituye más que un juicio hipotético sin valor alguno por sí solo para enervar la presunción de inocencia de los implicados.

debe dar traslado al Ministerio Público de aquellos atentados contra la legalidad urbanística que puedan ser constitutivos de delito. [...] muchos delitos urbanísticos se han podido cometer gracias a la corrupción, pero para perseguir esos delitos sería normalmente preciso (aunque no sea necesario) el correspondiente tanto de culpa remitido por la Administración, que en los casos de corrupción no lo hará, entre otras razones porque el objeto del pacto corrupto puede ser precisamente que la Administración mire para otro lado durante la ejecución de la obra ilegal o delictiva". 
De ahí entonces, la extraordinaria relevancia que actualmente encuentra en nuestro sistema penal la prevaricación como instrumento capital en la lucha contra el fenómeno de la corrupción.

\section{Breve introducción al delito de prevaricación administrativa}

Tanto la doctrina académica como la doctrina jurisprudencial han repetido hasta la saciedad que el delito de prevaricación, en cualquiera de sus modalidades, no puede ni debe sancionar la mera contrariedad de las resoluciones administrativas con el ordenamiento jurídico administrativo ${ }^{7}$.

Únicamente aquellas resoluciones administrativas cuya contrariedad con el ordenamiento vigente resulte patente, por manifiesta y grosera podrán ser adjetivadas como prevaricantes. Opción lógica, por lo demás, en tanto que lo contrario no sólo supondría una quiebra del principio de fragmentariedad del Derecho penal, sino que asimismo conduciría a una suerte

7 HAVA GARCÍA, E.: "Prevaricación de los funcionarios públicos", en F. Javier ÁLVAREZ GARCÍA, Tratado de Derecho Penal Español, Parte Especial, III. Delitos contra las Administraciones Públicas y de Justicia, Valencia, 2013, p. 136: "No toda resolución ilegal dictada por autoridad o funcionario público en un asunto administrativo es típica a efectos de lo dispuesto en el art. $404 \mathrm{CP}$, sino sólo aquellas que resulten "arbitrarias", cualificación que obliga a distinguir las ilegalidades cuyo control corresponde a la jurisdicción contenciosa de las que, trascendiendo ya el estricto ámbito administrativo, suponen la comisión de un delito de prevaricación por vulnerar abiertamente los principios constitucionales de la imparcialidad, igualdad de oportunidades, de legalidad, etc... que conforman la actuación de la Administración. [...] En cualquier caso, la interpretación del término "arbitraria" que realiza tanto la jurisprudencia como la doctrina mayoritarias tiene la virtud de aclarar que, desde una perspectiva objetiva, el injusto de la prevaricación requiere una infracción del principio de legalidad tan grave como para suponer la nulidad de pleno derecho del acto [...] por constituir estos supuestos las lesiones más clamorosas del bien jurídico protegido". 


\title{
de solipsismo entre la jurisdicción penal y la contencioso-admi- nistrativa ${ }^{8}$.
}

\author{
A la vista de lo antedicho, lógico sería pensar que el aná- \\ lisis de los casos de prevaricación debiera resultar relativamente
}

8 Así lo habría venido entendiendo el Tribunal Supremo de modo pacífico. A modo de ejemplo STS n ${ }^{\circ}$ 600/2014 ( $\mathrm{n}^{\circ}$ recurso: 1853/2013): "La condición arbitraria de la resolución es un aliud cualitativamente diferente de la mera ilegalidad que puede ser revisada vía recurso contencioso administrativo. La contradicción patente y clamorosa con el Derecho puede manifestarse según reiterada jurisprudencia, a) bien porque se haya dictado sin tener la competencia legalmente exigida, b) bien porque no se hagan respetado las normas esenciales del procedimiento, c) bien porque el fondo de la misma contravenga lo dispuesto en la legislación vigente, y d) suponga una grave desviación de poder-STS 727/2000-. En definitiva, se está ante una decisión prevaricadora como se dice en la sentencia recurrida, cuando se está ante un ejercicio arbitrario del poder: arbitrariedad que es la misma negación del Derecho y que está expresamente prohibida en el art. 9.3 de la Constitución". También STS 506/2014 (nº recurso: 2089/2013): "Se trataría, según expone el Tribunal de instancia, de una actuación administrativa e ilegal, en la que hay tanto injusticia como arbitrariedad, implicando una desviación clara de poder por parte de los dos acusados, que por su condición, debían ser plenamente conocedores de que una Administración Pública no puede prestar dinero municipal a algunos vecinos sin sujeción a reglas o procedimiento administrativo alguno. De conformidad con una jurisprudencia reiterada de esta Sala -STS 28/2014, de 23 de enero, con cita de otras muchas- los elementos del delito de prevaricación administrativa son los siguientes: en primer lugar, una resolución dictada por autoridad o funcionario en asunto administrativo; en segundo lugar, que dicha resolución sea contraria a Derecho, es decir, ilegal; en tercer lugar, que esa contradicción con el derecho u omisión de trámites, que puede manifestarse en la falta absoluta de competencia, en la omisión de trámites esenciales del procedimiento o en el propio contenido sustancial de la resolución, sea de tal entidad que no pueda ser explicada con una argumentación técnico-jurídica mínimamente razonable; en cuarto lugar, que ocasione un resultado materialmente injusto; y en quinto lugar, que la resolución sea dictada con la finalidad de hacer efectiva la voluntad particular de la autoridad o funcionario y con el conocimiento de actuar en contra del Derecho". ATS de fecha 3 de mayo de 2014 (n recurso: 20790/2013): "Por resolución injusta, pues, habrá de estimarse aquella que se aparte de todas las opciones jurídicamente defendibles, careciendo de toda interpretación razonable, siendo en definitiva exponente de una clara irracionalidad. La injusticia es por ello un plus respecto de la mera ilegalidad. Según se ha hecho patente en doctrina y jurisprudencia el elemento de injusticia se cifra ahora en el coeficiente de "arbitrariedad" de la decisión". 
sencillo, de modo que todos aquellos supuestos en que la autoridad o funcionario hubieran dictado resolución que no admitiera interpretación jurídicamente viable en Derecho bajo ningún prisma debieran ser siempre adjetivados como delictivos, procediéndose en sentido contrario en caso de que la resolución dictada, aún y siendo "incorrecta", fruto de su contrariedad con el ordenamiento jurídico administrativo, admitiera, no obstante, interpretación plausible en Derecho.

Desgraciadamente, lo cierto es que en la práctica el análisis de los supuestos de prevaricación no ha sido nunca, ni de lejos, tan sencillo, fruto de una, cuanto menos, controvertida configuración del elemento subjetivo.

Así las cosas, debe subrayarse que a pesar de que un sector doctrinal ciertamente cualificado habría venido postulando la admisibilidad del dolo eventual en el delito de prevaricación ${ }^{9}$, lo cierto es que la doctrina mayoritaria habría limitado su aplicabilidad a los supuestos de dolo de primer y segundo grado, al entender que las expresiones "a sabiendas de su injusticia" (arts. 404 y 320 Cp), "a sabiendas de su ilegalidad" (art. 405 Cp), o "a sabiendas", sin más, (art. 329 Cp), así lo exigen ${ }^{10}$. Conclusión ésta que a pesar de no compartirse será tomada como premisa en el presente trabajo.

9 SANZ-DÍEZ DE ULZURRUN, M.: Dolo e imprudencia en el Código penal español, Valencia 2007; GÓRRIZ ROYO, E.: Los delitos de prevaricación urbanística, Valencia 2004; FARALDO CABANA, P.: Ordenación del territorio, patrimonio histórico y medio en el Código penal y la legislación especial, Valencia, 2011; GONZÁLEZ CUSSAC, J.L.: El delito de prevaricación de autoridades y funcionarios públicos, Valencia, 1997; entre otros.

10 Entre otros, CANTERO, J.: La responsabilidad penal de los funcionarios por delitos ambientales, Madrid, 2010, p. 447: "La clave para determinar si es aceptable este dolo eventual en los arts. 320, 322 y $329 \mathrm{CP}$, se encuentra en analizar la fórmula final utilizada por el legislador para concretar el aspecto subjetivo de estos tipos. En efecto, no se introdujo el concepto multívoco de "intención" o "intencionalidad", ni el de "dolosamente"; tampoco se le exigió al funcionario actuar de "mala fe", que posiblemente puede expresar la exigencia de un dolo directo de primer grado: la expresión finalmente aceptada por el legislador penal fue "a sabiendas", que se 
En idéntico sentido, la jurisprudencia emanada de nuestro Tribunal Supremo y de nuestras Audiencias habría venido, de un modo unánime y pacífico, excluyendo la posibilidad de apreciar el dolo eventual en el delito de prevaricación.

\author{
En la práctica dicha configuración del elemento subjetivo \\ en el delito de prevaricación ha dado pie a que en un elevadísi- \\ mo número de casos las autoridades y funcionarios competentes
}

caracteriza, según el uso lingüístico actualmente uniforme de la ley, como exigencia siempre de dolo directo. [...] Con este componente subjetivo lo que se está queriendo decir es que el funcionario o autoridad ha de tener un conocimiento -en el sentido de entendimiento- seguro y pleno, un estado de consciencia, no sólo de la injusticia o arbitrariedad que su conducta va a acarrear, sino también de todos los demás elementos típicos de estos tipos penales. Y este conocimiento pleno, a mi entender, no se produce cuando el sujeto activo asume la probabilidad de que su acción pudiese ser antijurídica, sino únicamente acontece cuando comprende la clara arbitrariedad que va a realizar y a pesar de ello procede...".

Vid. asimismo, HAVA GARCÍA, E.: "Prevaricación de los funcionarios públicos", ob. cit., p. 140: "La referida expresión, en definitiva, hace referencia al dolo del sujeto, que en este caso consistirá en la voluntad de realizar el tipo con conocimiento de la "injusticia" de la resolución (esto es, de su carácter abiertamente ilegal-arbitrario), lo que parece que debe interpretarse como la imposibilidad de estimar supuestos de dolo eventual en la prevaricación administrativa. Así lo entiende la Jurisprudencia mayoritaria, en la medida en que exige una "intención deliberada" de realizar el hecho con plena conciencia de la ilegalidad e injusticia de la resolución[...] lo que excluye la apreciación de cualquier modalidad subjetiva distinta al dolo directo [...] dado que el legislador penal de 1995 decidió suprimir la modalidad imprudente del delito de prevaricación administrativa".

CATALÁN SENDER, J.: Los delitos cometidos por autoridades y funcionarios públicos, Barcelona, 1999, p. 60: "Se discute si puede cometerse con mero dolo eventual [...] lo cual es dudoso al tener difícil encaje el mero dolo eventual con la arbitrariedad palmaria, ya que ésta casa mejor con el dolo directo, pese a lo cual viene siendo admitido por un sector muy cualificado de nuestra doctrina".

ALONSO PÉREZ, F.: Delitos cometidos por los funcionarios públicos en el nuevo Código Penal: legislación, comentarios, jurisprudencia, Madrid, 2002, p. 215: "La intención dolosa o el repetido conocimiento de la ilegalidad no basta deducirla de consideraciones más o menos fundadas, sino que es necesario, como en todo derecho incriminatorio, una prueba evidente que no deje duda alguna del comportamiento anímico". 
para el dictado de las resoluciones prevaricantes hayan desarrollado, previo el inicio de la ejecución del delito, estrategias jurídicas dirigidas a dificultar la prueba de la concurrencia del dolo exigido por el tipo penal, valiéndose las más de las veces de informes técnicos que avalen su postura. Informes que, para mayor desvergüenza, en ocasiones son emitidos por los funcionarios del departamento competente, y en otras muchas, ante la negativa de estos a allanarse a las exigencias del cargo electo en cuestión, lo son por asesores externos contratados ad hoc con el fin de satisfacer las exigencias del cargo electo que pretende contar con un dictamen que avale su pretensión jurídica con el fin de evitar que pueda resultar acreditado su dolo directo o de segundo grado.

Circunstancia que usualmente permitirá a las autoridades y funcionarios responsables del dictado de la resolución arbitraria excluir su responsabilidad criminal, pues la mera alegación de la existencia del informe jurídico avalando el contenido de la resolución, unida a su falta de formación específica en la materia, les permitirá las más de las veces evitar tener por acreditado la existencia de dolo directo, justificando todo lo más la concurrencia de dolo eventual.

Dicha circunstancia exige el análisis de la configuración y límites de la responsabilidad del extraneus en el delito del intraneus, particularmente en relación a aquellas modalidades de prevaricación en las que la emisión de informes jurídicos o técnicos no ha sido expresamente elevada a la categoría de delito autónomo. Modalidades de entre las que destaca la prevaricación administrativa genérica (art. $404 \mathrm{Cp}$ ), toda vez que el legislador, sorprendentemente, no ha considerado oportuno establecer una modalidad $a d$ hoc en relación a los supuestos de prevaricación en la contratación administrativa, de suerte que a presar de tratarse de uno de los supuestos cuantitativa y cualitativamente más graves, resultará subsumible en la literalidad del art. $404 \mathrm{Cp}$, únicamente sancionado con pena de inhabilitación. 


\section{La participación en el delito de prevaricación administrativa}

La prevaricación administrativa en su modalidad genérica, al igual que en el resto de modalidades, se configura como delito especial propio, en tanto que únicamente describe como sujeto activo del delito a las autoridades y funcionarios competentes para el dictado de resoluciones administrativas, no existiendo modalidades delictivas en que subsumir la conducta de quienes sin ostentar aquella condición hayan dictado resolución en asunto administrativo.

A pesar de que la elección del legislador parece lógica, pues resulta evidente que sólo quienes ostenten aquella condición especial se hallarán legitimados para dictar resoluciones administrativas, careciendo de validez y eficacia y por ello de trascendencia para el bien jurídico las que fueran dictadas por otros sujetos, lo cierto es que el análisis detenido del tipo penal revela que dicha elección genera problemas de difícil solución técnica.

Las características del delito de prevaricación hasta el momento apuntadas -se trata de un delito especial propio que sólo admite su ejecución con dolo de primer o de segundo grado-, unidas al concepto de autor así como al modelo de accesoriedad de la participación en el hecho del autor mayoritariamente asumidos por nuestra doctrina y jurisprudencia, han originado notables dificultades a la hora de punir al extraneus en aquellos casos en que la conducta ejecutada por el intraneus no se hallara presidida por el elemento subjetivo exigido por el tipo penal.

La regulación en materia de autoría y participación contenida en nuestro ordenamiento jurídico positivo, principalmente en los arts. 27 a 29 del Código penal, tan sólo permite afirmar que nuestro legislador ha desechado asumir un concepto unitario de autor, en favor de otras tesis que si permitan distinguir entre autores y partícipes. Sin embargo existe general consenso en afirmar que en la actualidad nuestra doctrina y jurisprudencia 
han venido asumiendo mayoritariamente la teoría del dominio del hecho a la hora de delimitar entre autores y partícipes ${ }^{11}$, dato éste sumamente relevante en el análisis de nuestro objeto de estudio.

Asimismo, puede también afirmarse que nuestra doctrina y jurisprudencia mayoritarias han venido asumiendo las tesis de la accesoriedad limitada a la hora de delimitar las posibilidades de intervención punible del partícipe en el injusto del autor ${ }^{12}$.

11 MIR PUIG, S.: Derecho penal: parte general, Barcelona, 2004, pp. 372 y ss.: "La teoría del dominio del hecho constituye la opinión dominante en la doctrina alemana actual. Tiene su origen en el finalismo y en su tesis de que en los delitos dolosos es autor quien domina finalmente la ejecución del hecho, del mismo modo que ve lo decisivo de la acción en el control final del hecho. Mas actualmente se ha impuesto como teoría objetivo-subjetiva $y$, efectivamente aunque el dominio del hecho supone un control final (subjetivo), no requiere sólo la finalidad, sino también una posición objetiva que determine el efectivo dominio del hecho. [...] Esta concepción, acogida en España por un sector de opinión cada vez más amplio, puede ser objeto de algunas observaciones.

STS 303/2013, de 26 de marzo (recurso $n^{\circ}$ 1036/2012): Pese a todo, es cierto que esta Sala -en sintonía con la doctrina dominante-, ha convertido el principio de accesoriedad en uno de los fundamentos del castigo del partícipe y de este dato incuestionable hemos de partir para concluir la ausencia de la infracción legal que denuncia el recurrente. El principio de accesoriedad $[\ldots]$ no se explica por la relación entre el partícipe y el autor material, sino por la acción que uno y otro protagonizan. Pero para que pueda haber accesoriedad es indispensable que exista un hecho típicamente antijurídico [...] no se admite que la participación esté condicionada, sólo por una accesoriedad mínima. Cuestión distinta es la admisibilidad de la participación cuando el acto ilícito del autor no reúne todas las exigencias típicas. Nadie ha impedido al respecto la admisión como partícipe del sujeto en el que no concurren las objetivas condiciones típicas del autor en los denominados delitos especiales propios [...] En cuanto a la relevancia del componente subjetivo del tipo, el autor ha de actuar dolosamente.

En idéntico sentido STS 1394/2009, de 25 de enero (recurso: 10372/2009), STS 222/2010, de 4 de marzo (recurso 1231/2009); STS 214/2018, de 8 de mayo (recurso no 10311/2017).

12 PEÑARANDA RAMOS, E.: La participación en el delito y el principio de accesoriedad, Buenos Aires, 2018, p. 465: "En los sistemas como el nuestro la participación depende de que el hecho del autor principal muestre 
Admitido que la intervención del partícipe resulta dependiente, y por ello accesoria respecto del hecho ejecutado por el autor, se ha concluido que la participación punible presupone la previa realización de un hecho típico y antijurídico por quien ostente la condición de autor. No resultando sin embargo comunicables al partícipe las circunstancias que afecten a la culpabilidad del autor fruto de su carácter eminentemente personal, así como de su independencia respecto del injusto penal ${ }^{13}$.

MIR PUIG resume así el parecer mayoritario: "En favor de la teoría de la accesoriedad limitada, y en especial de la no dependencia del partícipe respecto de la posibilidad de imputación personal al autor, concurren diversos argumentos en el Código penal. Así, el significado de la palabra "hecho" (arts. 28 y $29 \mathrm{CP}$ ), empleada por la ley como presupuesto de las diferentes formas de participación, y que según se desprende de su uso en el art. $19 \mathrm{y}$ en los mismos $1^{\circ}, 2^{\circ}$ del art. $20 \mathrm{CP}$, no requiere la imputación personal del autor. Por otra parte los arts. 300 y 453 CP no sólo consagran el principio de accesoriedad limitada para la receptación y el encubrimiento, sino que confirma que el autor del hecho puede ser personalmente inimputable o hallarse exento de pena".

ciertas cualidades mínimes. Es a esta dependencia cualitativa y no meramente fáctica a la que se denomina accesoriedad. El alcance de esta dependencia será muy distinto, según se acoja el principio de la accesoriedad mínima, extrema o limitada. Las particularidades de esta cuestión son tan conocidas que no merece la pena insistir sobre elles. Basta con señalar que actualment se admite que en nuestro Derecho rige la accesoriedad limitada, esto es, la dependencia de un hecho principal típico y antijurídico"。.

13 MIR PUIG, S.: Derecho penal ..., ob. cit., 2004, p. 398: el principio de accesoriedad limitada de la participación. Significa, por una parte, que la participación es accesoria respecto del hecho del autor, pero también, por otra parte, que la participación es accesoria hasta cierto punto: basta que el hecho del autor sea contrario a Derecho (antijurídico). No es preciso que además sea personalmente imputable al autor (o como suele decirse: no es preciso que el autor sea "culpable"). Se descarta así la teoría de la accesoriedad máxima. 


\section{a) Supuestos en que el extraneus genera un error en el intraneus que le determina a dictar una resolución prevaricante}

Una vez llegados a este punto resulta evidente que la aplicación de la teoría del dominio del hecho en su formulación hoy en día imperante, ofrecida por ROXIN, así como de la teoría de la accesoriedad limitada, pueden conducir en el ámbito de la participación del extraneus en el delito del intraneus a soluciones político-criminalmente indeseables, así como dogmáticamente controvertidas, pues excluida la posibilidad de apreciar la autoría mediata, la estricta aplicación de ambas teorías debiera conducir, en el delito de prevaricación, a excluir la punición de quienes hubieran contribuido a la ejecución del delito, con independencia de la intensidad de su intervención, siempre que el intraneus no hubiera obrado de modo doloso.

Así las cosas, excluida la posibilidad de que quien no reúne las concretas condiciones personales exigidas por el tipo penal pueda ser considerado no ya tan sólo autor inmediato sino tan siquiera autor mediato del delito especial propio, ello, en buena lógica debiera conducir a la inevitable conclusión de la impunidad de quien deliberadamente genera un error en el intraneus que le determina decisivamente a dictar una resolución arbitraria. Así como de igual manera, a quien colabora con una aportación relevante al dictado de la resolución arbitraria en aquellos casos en que el intraneus obrara de modo imprudente, o incluso con dolo eventual.

A modo de ejemplo, cabría por lo tanto afirmar la atipicidad de la conducta desarrollada por el Secretario municipal que, consciente de los nulos conocimientos jurídicos de los miembros del órgano municipal competente para proceder a su adjudicación, emitiera informe preceptivo en expediente administrativo afirmando que un contrato de servicios por un precio de 300.000 euros pudiera ser adjudicado mediante contrato menor, generando así la creencia en los cargos electos competentes de obrar conforme a Derecho al realizar la adjudicación directa del contrato administrativo. 
Pues bien, si convenimos que el delito de prevaricación administrativa únicamente admite la ejecución dolosa, acreditado que quienes resolvieron la adjudicación directa por la vía del contrato menor obraron en la creencia de hallarse dictando una resolución ajustada a Derecho, no cabría sino afirmar la atipicidad de su proceder por ausencia del elemento subjetivo exigido por el tipo penal.

Lo anterior debería conducir inexorablemente a afirmar la atipicidad de la conducta desarrollada por el Secretario municipal, pues de acuerdo con la teoría de la accesoriedad limitada sólo cabría sancionar a quien ha colaborado en la ejecución de una conducta típica y antijurídica, resultado éste, el de la absolución del extraneus, que en ocasiones puede resultar indeseable desde una perspectiva político-criminal, y que no hace sino revelar la existencia de importantes deficiencias en la teoría de la accesoriedad limitada.

La Sala Segunda del Tribunal Supremo, ha tratado de eludir las consecuencias jurídicas de una estricta aplicación del principio de accesoriedad limitada en el ámbito del delito de prevaricación administrativa mediante la aplicación de una solución ciertamente controvertida ${ }^{14}$.

Así las cosas, ha venido en afirmar que el conocimiento de la contrariedad a Derecho de la resolución dictada por el autor del delito de prevaricación administrativa no se integraría en el tipo subjetivo sino en la culpabilidad. En opinión pacífica, unánime y reiterada de la Sala Segunda del Tribunal Supremo, el conocimiento de la injusticia y de la arbitrariedad de la resolución no se integrarían en el dolo natural o propio del tipo penal, sino en el denominado dolus malus, identificado con el conocimiento de la antijuridicidad, cuyo análisis se ubicaría en el seno de la culpabilidad. Reduciéndose de ese modo el contenido del dolo natural o típico al conocimiento del contenido de la resolución y a la voluntad de dictarla.

14 Entre otras vid. STS n ${ }^{\circ} 1026 / 2009$, de 16 de octubre; STS no 773/2014, de 28 de octubre; o STS n ${ }^{\circ} 303 / 2013$, de 26 de marzo. 
Asimismo, también de modo unánime y reiterado habría venido predicando que aquellos supuestos en los que el extraneus condujera a error al intraneus deberían ser sancionados como inducción al delito de prevaricación administrativa, toda vez que el extraneus habría generado en el intraneus el dolo típico propio del delito de prevaricación, que no debe olvidarse se reduce en la tesis del Tribunal Supremo a la voluntad de dictar una determinada resolución a sabiendas de su contenido.

De este modo, el Tribunal Supremo considera que se da cumplimiento a las exigencias de la accesoriedad limitada, pues así configurado el elemento subjetivo, debiera concluirse que el intraneus habría cometido al dictar la resolución administrativa arbitraria un hecho objetiva y subjetivamente típico además de antijurídico, si bien no culpable por concurrir un error de prohibición que excluiría la culpabilidad del autor del delito.

Se transcribe, por su claridad, lo señalado por el alto Tribunal en su STS 303/2013, de 26 de marzo (recurso: $n^{\circ}$ 1036/2012):

"Nada ha impedido al respecto la admisión como partícipe del sujeto en el que no concurren las objetivas condiciones típicas del autor en los denominados delitos especiales propios [...] En cuanto a la relevancia del componente subjetivo del tipo, el autor ha de actuar dolosamente. [...] Pero no se requiere que el dolo del autor sea el denominado dolus malus que implica una representación del sujeto sobre la oposición entre su comportamiento y el Derecho. Es suficiente el denominado dolo natural o, si se quiere, dolo típico referido al hecho típico. En el delito de prevaricación ese dolo implica el conocimiento del contenido de la resolución que dicta el funcionario y la voluntad de adoptarla. Pero no implica que el autor lleve a cabo una valoración del contenido de la resolución [...] La valoración por el autor sobre la trascendencia jurídica de su comportamiento se inserta ya en el dolus malus como parte de la imputación personal o culpabilidad. En consecuencia, como dejamos dicho con anterioridad, el conocimiento por el autor de la relación objetivamente preva- 
ricadora del contenido de ésta, unido a que dicho contenido sea arbitrario, satisface el juicio de antijuridicidad y es suficiente para justificar la exigencia de responsabilidad al partícipe. Quien haya ocasionado una errónea valoración para el funcionario del contenido de la resolución objetivamente arbitraria, determinando así en éste la voluntad de adoptarla, determinó la realización del hecho injusto a que se refiere el artículo 28 del Código penal, por más que el funcionario autor no sea culpable del delito de prevaricación por no actuar "a sabiendas" de la injusticia de su resolución".

A pesar de que la solución ofrecida por el Tribunal Supremo parece ciertamente ingeniosa, no cabe desconocer que su corrección resulta cuanto menos discutible desde una perspectiva técnica ${ }^{15}$.

15 VIDAL CASTAÑÓN, A.: “¿Argumentación o pretexto? A propósito de la fundamentación jurídica del Tribunal Supremo español para condenar a los partícipes en determinados casos donde no se castiga al autor del hecho principal", en Diario La Ley, $\mathrm{n}^{\circ}$ 8321, 2014: "Como hemos visto, el posicionamiento de nuestro Tribunal Supremo se aleja de tales premisas básicas, pues afirma que la antijuridicidad del hecho cometido por el Conseller se integra, únicamente con el dictar o firmar la resolución objetivamente injusta, sin parar a examinar si ello obedece a una conducta peligrosa de es sujeto. Es una exigencia legal que exista dolo o imprudencia en el sujeto activo para que pueda afirmarse la antijuridicidad penal (art. $10 \mathrm{Cp}$ ). Y lo que parece que hace aquí nuestro Alto Tribunal es construir, de forma cuestionable, la antijuridicidad penal del hecho del Conseller, afirmando que existe dolo típico en su conducta. Para ello no tiene más remedio que reducir el contenido de ese dolo típico al mero hecho de que el Conseller sabe y conoce que dicta una resolución sin más. El argumento que utiliza para salvar su postura es el manifestar que la resolución que firma el Conseller era "objetivamente injusta", por lo que dictar esa resolución colmaba el juicio de antijuridicidad. De esta forma, entiende que el conocimiento de la injusticia o arbitrariedad de la resolución no integra el tipo subjetivo, sino el conocimiento de la antijuridicidad. No parece un argumento convincente, por las razones expuestas, a lo que se añade el hecho de que, de forma abiertamente pacífica, nuestro Tribunal Supremo ha entendido y entiende que en el delito de prevaricación, el conocimiento de la injusticia o arbitrariedad de la resolución integran, precisamente, el tipo subjetivo. La contradicción no puede ser más evidente". 
En primer lugar, toda vez que parece artificioso reducir el contenido del dolo típico en el delito de prevaricación administrativa, vista la redacción ofrecida por el legislador al art. $404 \mathrm{del}$ Código penal, al conocimiento del contenido de la resolución así como a la voluntad de dictar la misma. Pues si la acción típica consiste precisamente en dictar una resolución arbitraria e injusta parece lógico pensar que el contenido del dolo típico debiera incorporar el conocimiento de la arbitrariedad y de la injusticia de la resolución que se dicta. Lo contrario supondría afirmar que la arbitrariedad y la injusticia de la resolución no constituirían en estos casos elementos del tipo, lo que indefectiblemente arrojaría la conclusión de que la acción típica se reduciría a dictar una resolución. Solución ésta difícilmente aceptable pues implicaría asumir que el legislador habría descrito como típica una acción no disvaliosa.

No cabe pues, sino concluir que la arbitrariedad e injusticia de la resolución constituyen elementos que se integran en el tipo objetivo, y que por lo tanto deben ser abarcados por el dolo del sujeto activo del delito ${ }^{16}$.

A mayor abundamiento, debe señalarse que aún y en el supuesto de que se aceptase la reducción del dolo típico antes referida, seguiría resultando discutible que la conducta desarrollada por el extraneus en estos casos pudiera ser calificada como inducción, en lugar de como autoría mediata. Pues lo cierto es que en la

16 MARTÍNEZ-BUJÁN PÉREZ, S.: Derecho penal económico y de la empresa: Parte General, Valencia, 2016, pp. 85 y ss.: "Pues bien, en base a tales premisas, cabe llegar a mi juicio, a la conclusión de que, en lo que atañe a los términos normativos jurídicos pertenecientes al denominado Derecho penal accesorio, señaladamente el socioeconómico (caracterizado precisamente por su "accesoriedad asimétrica", un error sobre el significado de tales términos (trátese te términos normativos en sentido estricto, de términos de valoración global del hecho o de normas penales en blanco) deberá ser tratado en la práctica totalidad de los casos como un error sobre el tipo. La razón estriba precisamente en el hecho de que en este ámbito el error sobre la norma extrapenal priva al sujeto del conocimiento del significado social del hecho o del sentido material auténtico del tipo penal. Y así lo entiende mayoritariamente la moderna doctrina, tras un largo y fructífero debate...". 
actualidad la doctrina mayoritaria viene pregonando que incluso en aquellos supuestos en que el error generado por un tercero lo fuera de prohibición, aun y cuando el mismo fuera considerado vencible, ello supondría una instrumentalización del ejecutor material del ilícito penal constitutiva de autoría mediata ${ }^{17}$.

Ciertamente cabría alegar en favor de la caracterización como inducción de los supuestos de hecho objeto de análisis que, caso de convenir que el ejecutor material de la conducta obró dolosamente, su actuar no fue ciego, sino que lejos de ello, tuvo acceso a todos los elementos del tipo, de suerte que dominó el hecho.

Sin embargo, lo cierto es que si el fundamento de la autoría mediata en los supuestos de error radica en la instrumentalización del ejecutor material, instrumentalización que operaría en aquellos casos en que dicho sujeto no obrase autónomamente sino mediatizado por el hombre de atrás, no cabría sino afirmar que los supuestos en que el extraneus condujera a error al intraneus haciéndole creer que el contenido de la resolución dictada resulta ajustado a Derecho debieran ser considerados constitutivos de autoría mediata, en tanto que el intraneus no habría dispuesto al momento de ejecutar la conducta de una verdadera capacidad de autodeterminación de su comportamiento con arreglo a la norma a causa del error subyacente ${ }^{18}$.

17 Sólo a modo de ejemplo, QUINTERO OLIVARES, G.: Parte General del Derecho penal, editorial Aranzadi, Navarra, 2010; Santiago MIR PUIG, Derecho Penal: Parte General, ob. cit., GÓMEZ RIVERO, M.C.: La inducción a cometer el delito, editorial Tirant lo Blanch, Valencia, 2013; DE OLIVEIRA MONTEIRO, L.: La autoría mediata en los delitos imprudentes, editorial Tirant lo Blanch, 2013, MUÑOZ CONDE, F./ GARCÍA ARÁN, M.: Derecho penal, Parte General, Tirant lo Blanch, Valencia, 2015.

18 GÓMEZ RIVERO, M.C.: La inducción a cometer el delito, ob. cit., p. 233: "Entiendo por ello que dado que el error del autor afecta a un factor decisorio de la contemplación penal de su hacer, tanto en los casos de error de prohibición vencible como invencible el tratamiento del hombre de atrás debe ser el mismo que cuando provoca un error de tipo, en el que como hemos visto, caso de vencibilidad, la apreciación de la responsabilidad del autor por imprudente no excluye la autoría mediata del hombre de atrás. [...] En 
En definitiva resulta evidente que en supuestos como el indicado el intraneus no se encontrará en disposición de dominar el hecho, pues no será él quien disponga lo necesario para lograr que sea dictada una resolución que reúna las características

ambos casos, lo decisivo es la situación actual de efectiva falta de libertad en que se encuentra el autor en el momento de actuar debido a un error que por recaer sobre una categoría normativa, limita de forma penalmente relevante su voluntad, convirtiéndole así en instrumento de la voluntad del hombre de atrás".

Asimismo vid., DE OLIVEIRA MONTEIRO, L.: La autoría mediata ..., p. 380 y ss.: "Vista aisladamente en relación a un sujeto individualmente, la autonomía deja de existir cuando el sujeto ya no sea capaz de autodeterminarse, o cuando ya no se le pueda exigir que actúe de acuerdo con las normas, porque se encuentre en alguno de los supuestos de situación de necesidad en sentido amplio o, incluso, de miedo insuperable. En estas condiciones extremas, aunque pueda ser visto como autor material del hecho, no podrá ser llamado a responder como autor responsable por sus actos. [...] En los casos en los que el sujeto actúe con algún déficit que conduzca a un mero desvalor de injusto o a un grado de responsabilidad de su conducta se puede llegar a admitir que su autoría individual se ha visto afectada por estos déficits, pero sólo desde la perspectiva individual. [...] No estamos, por tanto, de acuerdo con el argumento de que la libertad del ejecutor en la adopción de la resolución delictiva, como baremo delimitador de la inducción frente a la autoría mediata, está necesariamente vinculada a la responsabilidad criminal del que ejecuta. [...] La relación de instrumentalización que sirve de fundamento a la autoría mediata puede plasmarse, entonces, en la siguiente imagen: determinar a la ejecución de una conducta a un sujeto que actúa sin la pena posibilidad o sin la plena capacidad, en el momento de los hechos, de oponer resistencia a la capacidad de determinación que ostenta el hombre de atrás. Y según entendemos, sólo será coherente admitir, con referentes estables, que un sujeto actúe instrumentalizado cuando se encuentre en algunas de las circunstancias de déficit personal que el ordenamiento jurídico reconoce. [...] El elemento clave para lograr esta diferenciación entre la instrumentalización y la conducta de la inducción está, según entendemos en el efecto que produce la influencia del hombre de atrás en la esfera de autonomía privada del sujeto de delante, afectando su libertad de decidir o de ejecutar lo previamente decidido, reconocida en términos normativos [...] En este sentido la línea divisoria entre una y otra figura se constituye a partir de la calidad de la intervención y en la inducción se caracteriza por “adoptar una especial posición en la formación de la voluntad del autor, y en convertirse así en desencadenante de ésta, pasando a segundo plano quien hubiese ideado el plan [...] A esta definición, sin embargo añadiríamos que la capacidad de incitación del inductor se ejerce sin el empleo del engaño 
de ser injusta y arbitraria. En tales casos, el intraneus se hallará en realidad, claramente mediatizado por el extraneus, quien, qué duda cabe, dominará la voluntad del aquel ${ }^{19}$.

Debe asimismo subrayarse que la posición del Tribunal Supremo acerca del contenido del elemento subjetivo en el delito de prevaricación administrativa resulta distinta en función del supuesto de hecho sometido a enjuiciamiento, siendo posible hallar sustanciales diferencias en el tratamiento del dolo típico entre aquellos casos en que el objeto de la controversia versó

sobre la percepción y/o el entendimiento de los elementos que repercuten en la caracterización del injusto [...] y de la responsabilidad [...] y sin empleo de coacción que pudiera repercutir en la antijuridicidad o en la exigibilidad del actuar conforme a Derecho. Con esto queremos evidenciar que la injerencia en la autonomía privada del sujeto de delante -a través del empleo eficaz del engaño o de la coacción- es el dato objetivo que caracteriza el injusto más grave del autor mediato y que no se da en la inducción.

19 DE OLIVEIRA MONTEIRO, L.: La autoría mediata..., ob. cit., p. 475: "Para que el error del instrumento pueda situar al hombre de atrás en una posición preponderante en la realización del hecho es necesario, en base a nuestras consideraciones iniciales, que el engaño utilizado por el hombre de atrás afecte a la esfera de autonomía privada del que obra por delante, repercutiendo en su libertad de decisión racional y reflexiva acerca de los factores y circunstancias que inciden sobre su propio comportamiento. [...] La utilización consciente de artificios para enmarcar datos objetivos de la realidad o para tergiversar el significado jurídico de un hecho en concreto, con la finalidad de conseguir que otra persona actúe, así como la determinación desde una posición preponderante a que otro lleve a cabo una conducta peligrosa $[\ldots]$ tiene un sentido claramente distinto a la inducción. Constituye un mayor desvalor de injusto que según concebimos merece situar este tipo de actuación en el ámbito de la autoría, incluso cuando el autor directo hubiera podido superar el error [...] Lo que debe existir es instrumentalización, es decir, que el hombre de atrás actúe conscientemente con la intención de aprovecharse del específico déficit cognitivo que sufre el sujeto de delante". Asimismo, vid. BACIGALUPO, E.: "Cuestiones de la autoría y la participación en el delito fiscal", en Diario la Ley, $\mathrm{n}^{\circ}$ 8715, 2016: "Como hemos señalado, inductor es quien genera el dolo del autor directo. Por lo tanto, es conceptualmente imposible que aplicando los principios de la accesoriedad limitada, como hizo el Tribunal Supremo, quepa admitir la inducción del que no generó el dolo en los autores directos. [...] La accesoriedad limitada no modifica el concepto de inducción, sino que a obliga a no confundir el dolo con la culpabilidad. 
sobre la posible punición del extraneus cuando el intraneus obró sin conocimiento de la contrariedad a Derecho de la resolución dictada, y aquellos otros en que el objeto de la controversia sometida a enjuiciamiento tuvo por objeto la responsabilidad criminal del intraneus.

Así, mientras que en el primero de los supuestos de hecho referenciados, tal y como ya tuvimos ocasión de analizar, la Sala Segunda del Tribunal Supremo habría venido afirmando que el dolo típico aparecería integrado por el conocimiento del contenido de la resolución y la voluntad de dictarla, quedando el conocimiento de la arbitrariedad e injusticia de la resolución reservados para el análisis de la culpabilidad, en el segundo de los mismos el alto Tribunal habría venido identificando sistemáticamente el dolo típico con el conocimiento de la injusticia y arbitrariedad de la resolución administrativa ${ }^{20}$.

En mi opinión semejante paradoja no hace sino revelar que, en realidad, la construcción desarrollada por la Sala Segunda del Tribunal Supremo en relación a la configuración del dolo

20 STS 949/2007, de 14 de noviembre (recurso: 531/2007): "Para valorar la existencia del ánimo subjetivo imprescindible para integrar el delito de prevaricación que exige actuar a sabiendas de la injusticia es necesario analizar si las resoluciones [...] se hacen con conocimiento específico de que se tratan de decisiones absolutamente improcedentes y movidas por el único objeto de que perjudicar los derechos por la vía del silencio administrativo. STS 343/2018, de 10 de julio (recurso: 1349/2017), "No puede negarse la intencionalidad. No es un mero dolo eventual: el acusado había de conocer necesariamente ese desajuste de los procedimientos marcados".

STS 302/2018, de 20 de junio (recurso: 1215/2017): “... se trata de actuaciones dolosas realizadas con conciencia y voluntad de alterar el procedimiento administrativo. La emisión del voto se conecta con el dictado de adjudicación que por concurrencia del dolo conlleva la comisión del delito del art. $404 \mathrm{Cp}$, ya que como apunta la Fiscalía solo comete el delito quien conociendo la arbitrariedad de la resolución a sabiendas de su injusticia la asume con su voto.

STS 624/2013, de 27 de junio (recurso: 2304/2012): “Ahora bien, el delito de prevaricación administrativa, tiene como elemento subjetivo que los autores hayan actuado "a sabiendas", lo que supone un elemento subjetivo del tipo necesario para el delito". 
típico del delito de prevaricación administrativa en los casos de participación del extraneus en el delito del intraneus en que éste ignore la injusticia y arbitrariedad de la resolución dictada resulta a todas luces artificiosa. Apareciendo como una solución ad hoc con el fin de eludir las indeseables consecuencias políticocriminales que en caso contrario se sucederían.

Por si lo dicho hasta el momento no fuera bastante para tener por acreditada la anterior conclusión, debe subrayarse asimismo que, sorprendentemente, la configuración del conocimiento de la injusticia y la arbitrariedad de la resolución prevaricante como elementos de la culpabilidad, no habría venido dando lugar en ningún caso a la sanción de las autoridades y funcionarios responsables del dictado de las resoluciones. Solución ciertamente difícil de entender desde una perspectiva estrictamente dogmática, pues no debe olvidarse que conforme a lo preceptuado por el art. 14.3 del Código penal, la apreciación de un error de prohibición vencible deberá conducir a la sanción del sujeto en quien recae, si bien con rebaja de la pena a imponer en uno o dos grados.

No obstante, muy al contrario de cuanto aquí se afirma la Sala Segunda del Tribunal Supremo ha llegado a concluir que, en el ámbito del delito de prevaricación se debe ofrecer idéntico tratamiento al error de tipo y al error de prohibición, resultando indiferente que éste sea vencible o invencible, pues en cualquier caso, atendida la concreta estructura de aquel delito, procederá declarar la ausencia de responsabilidad criminal en el intraneus.

Así se pronuncia la Sala Segunda del Tribunal Supremo en su Sentencia ${ }^{\circ}$ 676/2014, de 15 de octubre (recurso $n^{\circ}$ 411/2014): "El motivo de la absolución es distinto. La Sala ha llegado a la certeza de que el acusado al aprobar la licencia actuaba convencido de ajustarse a la ley, aunque no fuera así, aunque esa creencia fuera errónea. [...] es palmario que la prevaricación de funcionario público es incompatible con una situación de error tanto vencible como invencible. El tipo penal -tanto en la modalidad genérica, art. 404, como en la específica en materia 
de ordenación urbanística -art. 320- exige obrar a sabiendas, lo que expulsa del Derecho penal los casos de error. Y eso con independencia de que calificásemos el error como de tipo o de prohibición. La modalidad de prevaricación imprudente sólo está tipificada en relación al juez o magistrado".

Pronunciamiento éste que no hace sino revelar, una vez más, que la construcción desarrollada por el Tribunal Supremo para los supuestos objeto de estudio se dirige exclusivamente a evitar lagunas de punibilidad, circunstancia que a su vez le lleva a tratar de facto el conocimiento de la arbitrariedad y la injusticia como elementos del tipo, aún y configurar aquel conocimiento, con el fin de permitir la sanción del extraneus, como elemento de la culpabilidad.

b) Supuestos en que el extraneus contribuye dolosamente al dictado de la resolución prevaricante cuando el intraneus hubiera obrado sin conocimiento de la contrariedad a Derecho de la misma

Lo dicho hasta el momento resulta en líneas generales extrapolable a los supuestos donde el extraneus contribuye dolosamente a la lesión del bien jurídico tutelado por el delito de prevaricación administrativa en que, no obstante, el intraneus hubiera obrado ignorando el carácter prevaricante de la resolución por él dictada.

Así las cosas, en aplicación de la teoría de la accesoriedad limitada, para el caso de entenderse que la arbitrariedad e injusticia de la resolución constituyen elementos del tipo que deben ser abarcados por el elemento subjetivo, el error sobre los mismos por parte del intraneus debiera conducir también en estos casos a declarar la falta de responsabilidad de la conducta del extraneus. Conclusión ésta a todas luces indeseable desde una perspectiva político criminal, y que tal y como hemos tenido ocasión de examinar, la Sala Segunda del Tribunal Supremo ha tratado de evitar mediante una controvertida reconfiguración del dolo típico en el delito de prevaricación administrativa. 


\section{Actual estado de la cuestión}

Como no podría ser de otro modo, la doctrina, consciente de la problemática asociada a la participación en los delitos especiales propios, ha venido ofreciendo distintas soluciones. A continuación, y sin ánimo de exhaustividad expondré sintéticamente algunas de las que en mi opinión resultan de mayor interés.

1. La negación de la intervención punible del extraneus en el delito del intraneus en los delitos especiales propios.

Un importante sector doctrinal, si bien minoritario, que tomaría como premisa la autonomía de lo injusto del partícipe, ha venido propugnando que la punición del extraneus en el ámbito de los delitos especiales debiera limitarse únicamente a los delitos especiales impropios.

Según este sector doctrinal los delitos especiales, singularmente los especiales propios, se caracterizarían porque en ellos la esencia de lo injusto penal se identificaría con la infracción de un deber extrapenal únicamente predicable de quien ostenta la condición de sujeto activo del delito. De ahí que la norma penal exclusivamente pueda entenderse dirigida a motivar a dicha clase de sujetos, quienes por ello serían los únicos que se encontrarían vinculados por la misma ${ }^{21}$.

21 GÓMEZ MARTÍN, Víctor.: Los delitos especiales, Madrid, 2006, p. 173 y ss.: "Un sector de la doctrina española considera, sobre la base de la noción de accesoriedad positiva o principal de la participación que el extraneus que participa en el delito especial de deber debe quedar impune. Según este sector doctrinal, el injusto de la conducta del partícipe en el delito no deriva del injusto de la conducta del autor, sino que es uno propio principal no secundario. Según el planteamiento que ahora se expone, en este sistema de intervención, la relación de dependencia que determina la accesoriedad de la participación no se establece entre el instrumento y el autor, sino entre el interviniente y el hecho típico, que es, de este modo común a todos los intervinientes. [...] Así, por ejemplo en opinión de Robles los delitos especiales en sentido estricto se caracterizan porque en ellos el círculo de posibles autores se encuentra limitado a aquellos sujetos en los que recae un determinado deber jurídico especial. De este modo, sólo el intraneus podrá ser autor 
A la vista de ello, siendo que la infracción de los deberes en cuestión únicamente podría ser ejecutada en dicha clase de delitos por el sujeto activo de los mismos, no cabría sino concluir que tan sólo la conducta desarrollada por éste podría ser disvaliosa para el Derecho penal, y por ello merecedora del reproche penal.

No existiría sin embargo ningún inconveniente para sancionar a quienes hubieran favorecido con su colaboración la lesión del bien jurídico tutelado por la norma en aquellos casos en que el ordenamiento jurídico penal hubiera previsto un delito común en que el "extraneus" al delito especial propio resultara incardinable como sujeto activo, pues en tales casos la conducta de colaboración sí habría sido expresamente declarada disvaliosa por nuestro ordenamiento jurídico.

En mi opinión, la tesis apuntada debe ser rechazada fundamentalmente por tres motivos.

En primer lugar, debe recordarse que la doctrina absolutamente mayoritaria ha venido afirmando que la responsabilidad del partícipe resulta accesoria respecto de la del autor ${ }^{22}$. Solución ésta que tal y como ya hemos tenido ocasión de examinar con anterioridad ha sido admitida de modo pacífico por nuestra jurisprudencia al asumir de forma unánime y reiterada la teoría de la accesoriedad limitada.

Aún y exceder del objeto de estudio del presente trabajo, me gustaría apuntar que me parece cuanto menos difícil admitir que el injusto del partícipe no se halle estrechamente conectado

de un delito especial de deber, porque sólo el intraneus podrá ser autor de un delito especial de deber, porque sólo él podrá infringir el deber jurídico especial, ya que icho deber sólo recaerá sobre el propio sujeto cualificado.

22 En este sentido vid. GIMBERNAT ORDEIG, E.: Autor y cómplice en Derecho penal, 1966, p. 292: "Nuestra posición respecto del extraño que participa -sea como coautor, inductor, cooperador necesario o cómplice- en un delito especial (propio o impropio) no puede ser otra que la defendida respecto al parricidio, infanticidio y aborto honoris causa: el extraño responde en base al delito especial". 
al del autor del delito ${ }^{23}$, resultando accesorio del mismo, pues no debe olvidarse que la participación no constituye sino un favorecimiento a la lesión del bien jurídico protagonizada por el autor del injusto. Obviamente, los más elementales principios constitucionales exigen que el partícipe sea sancionado por su propio injusto, extremo éste que exigirá desarrollar un análisis autónomo acerca del carácter disvalioso de su concreta contribución ${ }^{24}$. Sin embargo, no por ello debe olvidarse que la conducta

23 Al respecto, vid. DÍAZ Y GARCÍA CONLLEDO, M.: Autoría y participación, en Revista de Estudios Jurídicos de la Justicia, n 10, 2008: "Si bien la cuestión es muy debatida, no me parece convincente la postura que defiende la ruptura del título de imputación. Basar esta ruptura en lo dispuesto en el art. $65.1 \mathrm{CP}$ para la transmisión de circunstancias personales o subjetivas es incorrecto, pues este precepto es aplicable, en mi opinión, sólo a las circunstancias modificativas genéricas y a no a elementos del tipo como es la cualificación en los delitos especiales. Tampoco la más correcta apelación a los concursos de leyes subyacentes en estos supuestos me parece convincente (entre otras cosas, porque no se dan esos supuestos en todos los supuestos). En virtud de, entre otras razones, el propio fundamento del castigo de la participación y las, en mi opinión, más satisfactorias consecuencias a las que conduce, me parece preferible la solución del mantenimiento del título de imputación, que podrá combinarse en algunos casos con el juego de las circunstancias modificativas genéricas. Por lo demás, debería meditarse seriamente sobre la conveniencia del establecimiento en la ley, como sucede en otros países, de una atenuación para el partícipe extraneus en un delito especial, dada su mayor lejanía al injusto típico de ese delito".

24 PEÑARANDA RAMOS, E.: La participación en el delito ..., ob. cit., p. 463: "Desde esta perspectiva se puede encontrar una respuesta segura a esas dos cuestiones que vienen ocupando la atención de la moderna doctrina jurídico-penal. Por un lado, la de si el injusto por el que se castiga al partícipe es "propio" o es "derivado" del injusto del hecho del autor. Por otro lado, la de si la accesoriedad sólo limita o también fundamenta la responsabilidad de los partícipes. La primera pregunta sólo puede ser contestada, a mi juicio, de un modo: nadie puede ser hecho responsable del injusto de otro. Lo que sucede es que el propio desvalor del hecho del partícipe sólo puede ser captado adecuadamente si se lo contempla en su relación con el comportamiento de otros sujetos. Una consideración global y no aislada de su conduca dentro del conjunto del acontecimiento es también aquí imprescindible. Con ello enlaza la contestación a la segunda pregunta. Precisamente la conexión de la acción del partícipe con la de otros intervinientes explica que se pueda hacer responsable a aquél por un delito que por sí solo no podria cometer". 
del partícipe jamás integrará la ejecución de los diversos elementos objetivos descritos por el tipo penal, al igual que tampoco acarreará la efectiva lesión del bien jurídico tutelado por la norma, pues se limitará a favorecerla. De ahí que el análisis del desvalor del acto desarrollado por el partícipe sólo resulte posible mediante el examen conjunto de la conducta desarrollada por el autor ${ }^{25}$.

25 QUINTERO OLIVARES, G.: Parte General del Derecho penal, Cizur Menor, 2009, p.646: "En resumen, no hay ninguna regla que impida lo que es lógico, que los partícipes en delitos especiales propios o impropios respondan penalmente de acuerdo con el tipo realizado por el autor principal, sea cual sea ese tipo. El partícipe no puede ser autor principal, pero no tiene nada que ver; el título de imputación (delito por el que se responde) es el mismo para todos. Los empeños por romper ese título sólo se comprenden, si se entiende que el artículo $65 \mathrm{CP}$ afecta tanto a circunstancias modificativas como a elementos típicos (interpretación sin base) y se olvida que la autoría principal es definida en el primer párrafo del art. 29 CP y en relación con cada tipo".

RUEDA MARTÍN, M.A.: La punición del partícipe extraneus en un delito especial y el artículo 65.3 del Código penal, Ricardo ROBLES PLANAS, en La responsabilidad en los "delitos especiales", Montevideo, 2014, pp. 419 y ss.: "Tampoco resulta convincente una cualificada posición doctrinal que estima que el partícipe extraneus (inductor, cooperador necesario y cómplice) en ciertos delitos especiales debe quedar impune, al margen de la regulación penal adoptada en el art. 65.3 del Código Penal, [...] Cuando un extraneus ha participado en un ataque al bien jurídico en el seno de estas estructuras sociales realizado por un intraneus que ostenta el dominio social típico o que abusa de su especial posición de dominio, su conducta (de partícipe) contiene el desvalor que expresa en el delito especial. Al partícipe extraneus no se le imputa un injusto ajeno, sino uno propio: en estos supuestos la imposición de la pena correspondiente al delito especial al partícipe extraneus se fundamenta en que con su comportamiento penetra en una estructura social o institucional en la que se ejercicio un domino social típico o se abusa de una especial posición de dominio se facilita el acceso al bien jurídico, y el partícipe extraneus, si conoce su concurrencia, aprovecha la presencia de tales elementos, $[\ldots]$ para su propio ataque al bien jurídico. El ámbito de protección de la norma de los delitos especiales abarca todos los ataques al bien jurídico en el seno de tales estructuras, de manera que al extraneus también le incumbe la prohibición penal contenida en el tipo correspondiente. 
Asimismo, debe indicarse que en cualquier caso una semejante propuesta parecería contradecirse con la literalidad del art. 65.3 del Código penal, en que el legislador prevé de un modo expreso la posibilidad de atenuar la pena del extraneus en los supuestos de inducción y cooperación necesaria. Resultando evidente que se trata de una previsión que de un modo explícito conduce a concluir que el legislador ha admitido la punición del extraneus en los delitos especiales propios. Pues no resultaría lógico pensar que dicha disposición resultara de exclusiva aplicación a los delitos especiales impropios caso de pretenderse la sanción del extraneus conforme al delito común, pues en tal caso la previsión legal contenida en el art. 65.3 del Código penal carecería de todo sentido.

\section{La posición de ROXIN}

Existe consenso en atribuir a Claus ROXIN la primera elaboración de la teoría de los phlichtedelikte o delitos de infracción de deber ${ }^{26}$.

Según ROXIN, la teoría del dominio del hecho, en la formulación imperante en la actualidad por él desarrollada, no resultaría válida para ofrecer un tratamiento satisfactorio a una determinada clase de delitos caracterizada por la configuración de lo injusto penal en torno a la infracción de determinados deberes extrapenales por parte del sujeto activo del delito, que se erigirían en fundamento de lo injusto.

En estos supuestos la delimitación entre autoría y participación, según ROXIN, se desarrollará al margen de quien goce del dominio del hecho, atendiendo a la circunstancia de ostentar

26 BACIGALUPO, S.: Autoría y participación en delitos de infracción de deber, Barcelona, 2008, p. 53: "La categoría de los delitos de infracción de deber fue propuesta por Claus ROXIN en su obra Taterschaft und Tatherschaft en 1963. De acuerdo con la construcción allí realizada los delitos de infracción de deber se caracterizan porque en ellos el tipo penal requiera la infracción de un deber extrapenal que resulta ser el elemento básico de la autoría. Este elemento sería el que permite caracterizar a la figura central del suceso. 
la titularidad de los deberes en concreto vulnerados. De suerte que con independencia de la intervención que el titular de los deberes hubiera tenido en la ejecución del acto típico, siempre que concurriera en aquél el elemento subjetivo exigido por el tipo penal, el mismo debería ser considerado autor. Mientras que por el contrario, cualquiera que fuera la concreta intervención desarrollada por quien no fuera titular de aquellos deberes extrapenales, aún y cuando la misma se identificara con el dominio del hecho típico, deberá ser considerado partícipe ${ }^{27}$.

Llama la atención que en el sistema de la teoría del delito desarrollada por ROXIN los criterios para delimitar entre autoría y participación resulten diversos en función del tipo de injusto ante el que nos encontremos, así como muy especialmente, la circunstancia de que no se distingan distintos grados de intervención al delito del intraneus en los delitos especiales, de suerte que con independencia de cual sea su concreta contribución al delito siempre deberán ser considerados autores del mismo quienes hayan infringido los deberes extrapenales tutelados por el ordenamiento jurídico penal.

27 ROXIN, C.: Derecho penal. Parte General, Tomo II, Especiales formas de aparición del delito, Madrid, 2014, pp. 179 y ss.: "Hay dos métodos con cuy ayuda el legislador puede emprender o inducir típicamente de una manera respetuosa con el principio nullum crimen una conducta típicamente delictiva. El primero consiste en la descripción más precisa posible de las conductas intolerablemente dañosas socialmente que pretende conminar con pena: los del asesinato, las lesiones [...] El segundo método consiste en la conexión con deberes constitutivos del tipo que han experimentado su concreción en los más diversos ámbitos del ordenamiento jurídico y cuya infracción provocadora o incluso únicamente no evitadora del resultado típico se conmina con pena. El legislador se sirve de este método en los casos en que lo decisivo para él no es la configuración o constitución externa de la conducta del autor, porque el fundamento de la sanción radica en que alguien contraviene las exigencias de prestaciones o rendimiento de un papel social por él asumido. En tale casos figura central entre varios intervinientes es quien infringe el deber pretípico que le incumbe [...] siendo indiferente la magnitud de la participación externa en el resultado o el dominio del hecho. Yo hablo en estos casos de delitos de infracción de deber. 
A partir de dichas premisas ROXIN concluye afirmando que ello debe conducir a la posibilidad de admitir la autoría mediata en los delitos especiales propios en los casos de instrumento doloso no cualificado en que el hombre de atrás ostente la condición de intraneus ${ }^{28}$.

No obstante, lo realmente interesante en la teoría desarrollada por ROXIN, en lo que a nosotros interesa, resulta de sus reflexiones acerca de la accesoriedad de la participación en el ámbito de los delitos de infracción de deber.

Según ROXIN, la teoría de la accesoriedad limitada no presupone la previa realización de un hecho principal doloso por parte del intraneus como condición necesaria para la punición de la participación del extraneus. De suerte que las exigencias derivadas del principio de accesoriedad limitada quedarían colmadas con la mera realización de un hecho objetivamente típico y antijurídico ${ }^{29}$. Y es que, tal y como señala Silvina BACIGALUPO si se concibe la participación en los delitos de infracción de deber no como una colaboración sin dominio del hecho, sino como una colaboración sin infracción de los deberes extrapenales que fundamentan la responsabilidad del autor, ningún problema debiera existir en admitir la posibilidad de excluir

28 ROXIN, C.: Derecho penal. Parte General, ob. cit., p. 182: "Las grandes diferencias que se producen en la delimitación de autoría y participación entre delitos de infracción de deber no cambian para nada el hecho de que sus conceptos de autor coinciden en el punto de referencia superior de la figura "figura central del suceso o acontecer típico". Sólo son diferentes manifestaciones de este principio rector.

29 ROXIN, C.: Derecho penal. Parte General..., ob. cit., p. 217: "No se le puede atribuir sin más a la exigencia de un hecho principal doloso el predicado o calificación de materialmente correcta o adecuada. Es dudoso si esa exigencia está incluida en el principio de accesoriedad limitada [...] Aún y cuando la opinión hoy dominante no se haga esa deducción sistemática, siempre se podría entender el principio de accesoriedad limitada de tal modo que para él, junto a la ventaja de la acción del autor, sólo sea preciso que se cumpla o realice el tipo objetivo. $\mathrm{Y}$ en todo caso, legislador podría haberlo dispuesto así. Se ha de respetar su decisión contraria, pero también se ha de lamentar. Pues abre incomprensibles lagunas de punibilidad. 
de la noción de accesoriedad en tales casos el elemento subjetivo del intraneus ${ }^{30}$.

\section{Propuesta personal}

Tal y como hemos tenido ocasión de analizar, el actual estado de la teoría del delito parece impedir, en relación a los delitos especiales propios, apreciar la participación del extraneus en el hecho principal no doloso o imprudente del intraneus. Circunstancia singularmente preocupante en lo que al delito de prevaricación administrativa se refiere si convenimos en atribuir a dicha modalidad típica, conforme a lo expuesto al inicio de este trabajo, una singular relevancia en la lucha contra la corrupción.

En mi opinión, la solución de tener por atípicas o irrelevantes penalmente las contribuciones desarrolladas por quienes no ostenten las concretas condiciones exigidas por el tipo penal en tales casos resulta no sólo inadmisible desde una perspectiva político-criminal, sino también dogmática y positiva.

a) Casos en los que el extraneus haya creado un error en el intraneus que le determine a dictar una resolución injusta y arbitraria.

En primer lugar, debe señalarse que la solución de la irresponsabilidad del extraneus en tales casos, parece contradecirse abiertamente con la voluntad del legislador, expresada en el art. 65.3 del Código penal.

30 BACIGALUPO, S.: Autoría y participación ..., ob. cit., pp. 70 y ss.: "De acuerdo con lo sostenido por ROXIN [...] se debe negar, junto con la doctrina dominante la participación en un hecho no doloso, pero sólo en los delitos de dominio. Si se admite que en los delitos de infracción de deber, por el contrario, constituyen una categoría independiente respecto de los delitos de dominio, en la que la autoría sigue siendo entendida como la figura central del suceso [...] La participación en los delitos de infracción de deber no se definirá ya como una "cooperación" sin dominio del hecho", sino como una "cooperación sin infracción del deber". A partir de esta definición, la estructura del delito de infracción de deber no se modifica por el hecho que infringe el deber actúe sin dolo". 
Recuérdese que según el referenciado precepto "Cuando en el inductor o en el cooperador necesario no concurran las condiciones, cualidades o relaciones personales que fundamentan la culpabilidad del autor, los jueces o tribunales podrán imponer la pena inferior en grado a la señalada por la ley para la infracción de que se trate". Previsión legal de la que inferir sin dificultad alguna la voluntad del legislador de sancionar cualesquiera modalidades de participación en los delitos especiales propios.

Siendo ello así, resultaría paradójico afirmar que el legislador, no obstante, de entre todas las posibles conductas desarrolladas por el extraneus para favorecer la lesión del bien jurídico protegido, habría decidido excluir aquellas que hubieran consistido en lograr el dictado de una resolución arbitraria mediante la instrumentalización del intraneus. Pues no en vano, dichas conductas resultarían de entre todas las que el exatraneus pudiera ejecutar, las que presentarían un mayor desvalor de acción en su ejecución.

Así, las cosas, resultando clara la voluntad del legislador, el hecho de que la actual teoría del delito impida apreciar en tales casos la responsabilidad criminal del extraneus fruto de la imposibilidad de éste de erigirse en sujeto activo del delito, y por ello en autor mediato, así como también de la imposibilidad de participar en un hecho principal no doloso, no hace sino revelar la existencia de grandes deficiencias en el sistema, que exigen, dada su gravedad, de una urgente subsanación.

Tampoco desde una perspectiva dogmática resulta razonable la solución de la irrelevancia criminal de esta modalidad de comportamientos.

Así las cosas, debe señalarse que si bien es cierto que resulta usual entender que buena parte de los delitos especiales propios, particularmente los denominados delitos de funcionarios, se caracterizan por construir lo injusto penal en torno a la noción de infracción de un deber extrapenal del que serían exclusivos titulares quienes reunieran las personales condiciones exigidas por el tipo penal, no lo es menos que no parece en 
ningún caso razonable entender que el fundamento principal de lo injusto penal en tales casos se identifique con la infracción de tales deberes.

Ciertamente, resulta perfectamente plausible que el legislador decida reducir el círculo de posibles sujetos activos a quienes reúnan determinadas condiciones, por entender que su intervención en la lesión del bien jurídico tutelado por la norma, atendidas las concretas condiciones concurrentes y en particular los singulares deberes inherentes a aquellas, convierten su comportamiento en particularmente disvalioso frente al resto de miembros de la comunidad. En definitiva, es al legislador a quien compete discernir de entre las numerosísimas modalidades de comportamiento reproducidas en sociedad cuales, fruto de su mayor disvalor así como lesividad para el bien jurídico -desvalor de acción y de resultado-, merecen ser sancionadas penalmente.

Ahora bien, ello en ningún caso permite perder de vista que el fundamento principal de lo injusto penal propio de un estado social y democrático de derecho debe ser la protección de los bienes jurídicos.

A mayor abundamiento, creo que existen buenas razones para afirmar que lo contrario implicaría una importante deriva hacia un sistema del delito próximo al propuesto por JAKOBS, en que el fundamento de lo injusto penal lejos de descansar sobre la protección de los bienes jurídicos en juego, lo haría sobre la idea de protección de las expectativas que todo ciudadano posee en el cumplimiento de la norma por parte del resto de miembros de la comunidad, y en particular sobre la noción de actuación conforme a roles predeterminados.

Anclado en los postulados epistemológicos del funcionalismo sistémico, JAKOBS entiende que el delito debe ser concebido como hecho social que expresa comunicativamente la falta de vigencia de la norma así como de los roles asignados al sujeto infractor, y que por ello supone una quiebra de las expectativas existentes sobre su cumplimiento, poniendo en riesgo el 
aseguramiento cognitivo de la colectividad. De ahí que la producción causal de un daño material a un bien jurídico resulte irrelevante para él, o, en todo caso, deba quedar relegada a un segundo plano ${ }^{31}$.

Por ello, precisamente, cabe afirmar que en el pensamiento de JAKOBS, el delito se concibe no como lesión de bienes jurídicos sino como mera infracción de deber, habilitándose con ello al legislador para desarrollar cualesquiera actuaciones en tanto que su edificio teórico parte del reconocimiento de la legitimidad, en todo caso, de la injerencia punitiva.

Según mi punto de vista, ello le conduce inexorablemente a enarbolar como emblema del sistema teórico del delito el principio de "seguridad" - principio esencial a través del que garantizar la protección de las expectativas- en detrimento de los conceptos de libertad y de autonomía de la voluntad, lo que si bien es cierto que desde un plano estrictamente abstracto puede resultar técnicamente válido, no lo es menos que implica un evi-

31 JAKOBS, G.: Sobre la normativización de la dogmática jurídico-penal, editorial Thomson Civitas, Navarra, 2003, pp. 59 y ss.: "La cuestión acerca del fin de la pena también puede plantearse en otro sentido distinto del que hasta ahora se ha discutido aquí: ¿para que sirve todo el "aparato penal”? La respuesta probablemente más extendida en Alemania es: para la protección de bienes jurídicos. En la segunda parte de esta intervención se pretende analizar críticamente esta respuesta, y la conclusión obtenida en la parte anterior, de acuerdo con la cual la pena debe ser entendida como una contradicción de la desautorización de la norma, ya preconfigura el resultado que se obtendrá en este punto: la pena no asegura bienes jurídicos, y mucho menos aún los repara, sino que asegura la vigencia de la norma. La protección de bienes jurídicos en todo caso se obtendrá como resultado mediato. [...] El significado puramente jurídico de la pena es la contradicción contra la infracción de la norma. [...] Un comportamiento que lesiona bienes y un comportamiento no permitido no son lo mismo, y con ello los bienes pasan definitivamente a un segundo plano, detrás de las relaciones entre personas".

Vid. Luhmann, N.: El derecho de la sociedad, ob. cit., p. 89: "la forma de operación que produce y reproduce el sistema de la sociedad es la comunicación plena de sentido. Esto permite afirmar que el sistema del derecho -en cuanto sistema parcial de la sociedad- no puede hacer otras cosas que crear formas (oraciones) en el medio del sentido a través de la comunicación". 
dente déficit de legitimidad axiológica incompatible, según mi criterio, con los postulados de un Estado social y democrático de Derecho.

La teoría de JAKOBS, de forma absolutamente consciente, pretende, en definitiva, proteger el status quo imperante, anulando con ello cualquier posibilidad de evolución social desestabilizante para el sistema, infiriéndose por ello que, a pesar de su carácter pretendidamente científico y avalorativo, se trata de una tesis que se construye bajo una particular concepción ideológica ${ }^{32}$.

Para JAKOBS, como seguidor de LUHMANN, la función del Derecho penal consiste en garantizar la estabilidad del sistema social, y de ahí la comprensión del delito como un mensaje comunicativo que expresa un sentido de quiebra de las expectativas sociales, así como de la sanción penal como mensaje que comunica la restauración de la vigencia de la norma y de las expectativas que han sido quebradas por el delito ${ }^{33}$.

Adviértase, asimismo, que en el sistema del delito de signo funcional sistémico de JAKOBS la significación delictiva de

32 Vid. JAKOBS, G.: Dogmática de Derecho penal y la configuración normativa de la sociedad, Navarra, 2004, pp. 75 y ss.: "Cuando la sociedad pena, se niega a concebir un cambio de su configuración, el hecho punible como un acto de evolución, como una parte de sus posibilidades, sino que por el contrario se mantiene firme en el statu quo, en contra de la propuesta de cambio. De la misma forma que una persona rechaza una pretensión que no encaja con su forma de ser, ratificando de esta manera esta forma de ser, así la sociedad rechaza la pretensión de abandonar la expectativa defraudada, ratificando con ello su identidad.

33 Vid. JAKOBS, G.: Dogmática de Derecho penal, ob. cit., pp. 75 y ss.: "El Derecho penal tiene por misión garantizar la identidad de la sociedad. Esto se lleva a cabo tomando el hecho punible en su significado, como aportación comunicativa, como expresión de sentido y además respondiendo ante él. [...] El hecho punible consiste en la defraudación de expectativas en sí misma, dicho de forma tradicional, en el quebrantamiento de la norma y no ya en las consecuencias psico-sociales de este quebrantamiento. Por consiguiente, al concepto de pena pertenece la ratificación de la existencia de la norma, esto es, la refutación del hecho que cuestiona esta existencia": 
las conductas trasciende al individuo, en tanto que el significado comunicativo de las acciones sólo puede ser determinado en sociedad.

De ahí que para JAKOBS la conciencia individual no determine el contenido del acto. ${ }^{34}$

Todo lo expuesto conducirá a JAKOBS a concluir que la atribución de un resultado a un sujeto únicamente podrá efectuarse conforme a parámetros normativos, de carácter intrasistémico, permitiéndole extraer un postulado: la comunidad con otro siempre es tan sólo una comunidad limitada. Los sujetos, en tanto que considerados por el subsistema jurídico como meras funciones normativas únicamente están obligados a cumplir las expectativas que les han sido asignadas.

Para JAKOBS, en aquellos casos en los que la conducta del sujeto interviniente, se desarrolle conforme a su función o rol, sin quiebra de las expectativas asignadas por la sociedad, no podrá entenderse que se haya ejecutado una conducta penalmente relevante de ninguna clase $^{35}$, y ello con independencia de la afectación que la acción haya tenido para bienes jurídicos penalmente tutelados.

34 Vid. JAKOBS, G.: Dogmática de Derecho penal y la configuración normativa de la sociedad, ob. cit., p. 84: "El significado de un comportamiento es su posición en el contexto social. No es suficiente pues poner la mirada en un causador, incluso quizás aunque se le tenga en cuenta junto con lo que ocurra psíquicamente, sino que la mirada debe dirigirse también a la víctima y a terceras personas, para poder atribuirle un suceso acaecido en el mundo material como su hecho o como su infortunio".

35 Vid. JAKOBS, G.: "Dogmática de Derecho penal y la configuración normativa de la sociedad", ob. cit., p. 127: "se trata de los casos en que existe una comunidad fundamentada en los contactos sociales, si bien en ningún caso absoluta, sino siempre limitada de determinada forma. Pues bien, en estos casos, las metas que sean pretendidas por uno de los miembros de esa comunidad más allá de lo común, no habrán de ser tenidas en cuenta por el otro componente de la comunidad. Hablando en términos ejemplificativos: La compra de objetos se agota en el intercambio de la mercancía por el dinero, y el pago de deudas en la liquidación del crédito; lo que el comprador haga con la mercancía, por ejemplo si la exporta de forma prohibida o si la 
De ahí que en mi opinión una deriva semejante pudiera conducir a un indeseable modelo autoritario.

En cualquier, caso, volviendo al tema que nos ocupa, el que el fundamento de lo injusto penal se erija en torno a la noción de bien jurídico, y no a la de infracción de deber, permite en buena lógica concluir que no existen motivos que justifiquen la exclusión del círculo de sujetos responsables a quienes contribuyan al hecho del intraneus, aún y no reunir las concretas condiciones personales exigidas por el tipo penal para ostentar la condición de sujeto activo del delito.

Dicho lo cual, debemos entonces preguntarnos cuál debe ser la solución para lograr sancionar a quienes, sin ostentar las concretas condiciones personales con que el tipo penal describe al sujeto activo del delito, generan, en quien sí goza de dicha condición, un error que le determina a dictar una resolución prevaricante.

En primer lugar parece oportuno plantear la posibilidad de sancionar como autoría mediata aquellos supuestos en que, sirviéndose de un instrumento cualificado, el hombre de atrás no cualificado condujera a error al primero, logrando de aquella forma el dictado de una resolución arbitraria.

En mi opinión si convenimos que en los delitos especiales propios la infracción de deber no se erige en fundamento de lo injusto penal, sino que en realidad lo hace la lesión del bien jurídico tutelado por la norma, no parece descabellado seguir acudiendo a la teoría del dominio del hecho para delimitar entre autoría y participación, siendo razonable concluir que el hombre de atrás dominaría de aquel modo la voluntad del intraneus.

Adviértase que de este modo, se evitan atribuciones formales de la condición de autor atendida la exclusiva circunstancia de reunirse las concretas condiciones exigidas por el tipo

usa por su parte para un negocio fraudulento o para la construcción de un paquete bomba, le interesa al vendedor tan poco, como al deudor le importa si el acreedor subvenciona a una organización terrorista con lo recibido o financia tráfico de armas prohibido". 
penal o la quiebra de un personal deber extrapenal, elementos que en mi opinión en ningún caso deben justificar la automática atribución de la autoría.

A la vista de ello, construyendo lo injusto penal de los delitos especiales propios en torno a la noción de bien jurídico, parece factible argumentar que el hombre de atrás se habría servido de las condiciones personales del intraneus para lograr la lesión del bien jurídico que sólo a él le está dado ejecutar como consecuencia de la concreta posición que ocupa en la realidad, siendo ello suficiente para colmar las exigencias típicas.

Es decir, si lo relevante en la configuración típica de los delitos especiales propios es la circunstancia de que, por una cuestión puramente fáctica y por ello accesoria, sólo la conducta del intraneus resulta idónea para lograr la lesión del bien jurídico protegido, atendida su concreta posición y vínculo respecto de éste, no identificándose la ejecución del delito con la infracción de deberes extrapenales, sino con la realización de una conducta típica idónea para lograr la lesión del bien jurídico, no parecería descabellado entender que en aquellos casos en que el hombre de atrás lograra colocarse en una situación fáctica idónea para lesionar el bien jurídico, éste pudiera ser considerado autor mediato.

En definitiva, se trataría de negarle carácter valorativo a las concretas condiciones exigidas por el tipo penal para erigirse en sujeto activo del delito, relegando aquellas a una mera circunstancia fáctica. Así, a modo de ejemplo, en relación al delito de prevaricación, implicaría afirmar que en realidad la decisión del legislador de reducir el círculo de posibles sujetos activos a autoridades o funcionarios públicos no implicaría juicio de valor alguno, sino que derivaría de la mera constatación fáctica acerca de que en la realidad los únicos sujetos con capacidad para dictar una resolución son aquellos.

Claro ejemplo de cuanto se dice resulta de la circunstancia de que para el caso de modificarse la redacción del art. 404 del Código penal en el sentido de ampliar el círculo de posibles sujetos activos mediante el empleo de la fórmula "el que...", 
ello en nada modificaría el carácter de delito especial propio del tipo penal, pues los únicos sujetos que seguirían gozando de capacidad para dictar una resolución arbitraria seguirían siendo aquellos a quienes la legislación atribuya competencias para dictar resoluciones, esto es, autoridades y funcionarios.

De ahí que parezca viable concluir que en aquellos casos en que un sujeto no cualificado lograra subrogarse en la posición de otro que si lo estuviera, logrando de aquel modo acceder al bien jurídico, debiera poder ser considerado autor.

En contra de la solución propuesta cabría afirmar que la circunstancia de que tan sólo determinados sujetos se hallen en disposición de ejecutar una determinada conducta típica, o lesionar el bien jurídico, en realidad sí subyace un juicio de valor, pues qué duda cabe de que en efecto la infracción de los deberes extrapenales inherentes al cargo pudiera conducir a la consideración de un mayor desvalor del acto, así como a una mayor exposición para el bien jurídico. Afirmación, ésta, no obstante, a la que cabría objetar que no corresponde al Derecho penal conocer del reproche por la infracción de deberes extrapenales. Así, a modo de ejemplo, en el caso de infracciones cometidas por funcionarios resultará usual que junto a la sanción penal el funcionario sea disciplinariamente sancionado sin que ello comprometa el principio non bis in ídem, a causa del distinto fundamento de la sanción.

Con todo, lo cierto es que la solución expuesta pudiera plantear problemas de subsunción en la literalidad del art. 28 del Código penal, pues según opinión doctrinal dominante, del mismo se infiere la necesidad de que tanto el autor inmediato como el mediato reúnan las concretas condiciones exigidas por el tipo penal para ser considerado sujeto activo del mismo. Todo ello sin olvidar las dudas de compatibilidad con el principio de legalidad, pues la propuesta aquí formulada pudiera implicar una interpretación extensiva del tipo en contra de reo $^{36}$.

36 En este sentido vid. PEÑARANDA RAMOS, E.: La participación en el delito..., ob. cit.; QUINTERO OLIVARES, G.: Parte General del Derecho 
Asimismo, la tesis expuesta también parecería contradecirse con las previsiones del art. 31 del Código penal, toda vez que si el legislador ha incorporado una cláusula de ampliación del ámbito típico en los supuestos de actuación en nombre o representación de otro, la omisión de una cláusula similar de aplicación en los casos de creación de error en el intraneus pudiera interpretarse en el sentido de que el legislador ha tenido a bien no considerar penalmente relevantes dichos comportamientos.

A la vista de todo lo expuesto hasta el momento, creo que la verdadera solución a los problemas que en la actualidad parecen impedir la punición de los supuestos de hecho sometidos a examen debe pasar por una reforma legislativa a través de la que se incorpore al Código penal una cláusula que de un modo expreso habilite la punición de los autores mediatos no cualificados en el ámbito de los delitos especiales propios. Pues lo contrario, como resulta evidente, no hará sino condenar a nuestra jurisprudencia a seguir realizando malabarismos dogmáticos con el fin de colmar las indeseables lagunas de punibilidad existentes. Ninguna excusa existe para que el legislador no aborde la reforma que aquí se propone, cuando lo cierto es que resulta evidente su voluntad por sancionar la participación del extraneus en los delitos especiales propios, y las extraordinarias dificultades que la ausencia de dicha previsión normativa provoca.

b) Supuestos en los que el extraneus contribuye al hecho principal subjetivamente atípico del intraneus

No quisiera poner punto y final al presente trabajo, sin antes efectuar unas breves consideraciones acerca de la posibilidad de admitir la participación por parte del extraneus en un hecho principal subjetivamente atípico ejecutado por el intraneus.

Para ello, me gustaría tomar como punto de partida las reflexiones desarrolladas al respecto por ROXIN: "No se le pue-

penal, ob. cit; MIR PUIG, S.: Derecho Penal: Parte General, ob. cit, MUÑOZ CONDE, F./ GARCÍA ARÁN, M. Derecho penal, Parte General, ob. cit. 
de atribuir sin más a la exigencia de un hecho principal doloso el predicado o calificación de materialmente correcta o adecuada. Es dudoso si esa exigencia está incluida en el principio de accesoriedad limitada, de modo que la mención expresa de un hecho cometido "dolosamente" en los arts. 26 [inducción] y 27 [cooperación o complicidad] sería en realidad superflua. [...] Aun cuando con la op. hoy absolutamente dom., no se siga esa deducción sistemática, siempre se podría entender el principio de accesoriedad limitada de tal modo que para él, junto a la antijurdicidad de la acción del autor, sólo sea preciso que se cumpla o realice el tipo objetivo". Y en todo caso, el legislador podría haberlo dispuesto así. Se ha de respetar su decisión contraria, pero también se ha de lamentar. Pues abre incomprensibles lagunas de punibilidad" ${ }^{\prime 37}$.

Adviértase, así pues, que ROXIN no sólo propone la admisibilidad de la participación al hecho principal subjetivamente atípico en la categoría de los delitos de infracción de deber, toda vez que en ellos la delimitación entre autoría y participación se desarrolla extramuros de la teoría del dominio del hecho, sino que en realidad predicaría aquella solución con carácter general.

Solución que, por lo demás, también ha venido postulando de modo expreso desde hace ya algunos años MARTÍNEZBUJÁN, si bien desde los postulados de la concepción significativa de la acción ${ }^{38}$.

37 ROXIN, C.: Derecho penal. Parte General, ob. cit., p. 217.

38 MARTÍNEZ-BUJÁN PÉREZ, C.: El contenido de la antijuridicidad (Un estudio a partir de la concepción significativa del delito), Valencia, 2013, pp. 92 y ss.: "Así las cosas, aunque VIVES no se haya pronunciado explícitamente sobre el alcance concreto de la clase de accesoriedad que se deriva de la concepción significativa del delito, lo más congruente es, en mi opinión, acoger una caracterización de la accesoriedad que vaya referida a un tipo de acción en sentido estricto, delimitado según las pretensiones de validez delineados por la concepción significativa, a saber: una accesoriedad referida a un tipo de acción materialmente u objetivamente antijurídico, que consecuentemente no incluye la vertiente subjetiva (integrada en la pretensión de ilicitud o antijuridicidad formal). Y es que, en efecto, una accesoriedad así concebida es la que mejor se acompasa con la nítida distinción 
Con todo, lo cierto es que en nuestro país se ha venido por lo general negando la posibilidad de la participación en el hecho principal subjetivamente atípico tomando como fundamento la literalidad del art. 29 del Código penal, que en su opinión así lo impediría, toda vez que dicho precepto impondría como presupuesto de la punibilidad de la participación la previa realización de un hecho objetiva y subjetivamente típico, así como antijurídico ${ }^{39}$.

que aquí se mantiene entre antijuricidad material y antijuridicidad formal, bassda en dos diferentes pretensiones de validez de la norma, de tal manera que en la primera (la pretensión de relevancia) únicamente tiene cabida la vertiente objetiva del delito y en la segunda (la pretensión de ilicitud) queda incluida la vertiente subjetiva: en la primera se trata de constatar que concurre una acción relevante y objetivamente ofensiva para un bien jurídicopenal y en la segunda, que tiene lugar la infracción de la norma de conducta. [...] La conclusión que se acaba de obtener permite solventar satisfactoriamente y con sencillez el conocido y discutido problema que plantea el usualmente denominado caso del "testaferro" en delitos especiales que se construyen sobre la base de la infracción de un deber personal en el autor, [...] Pues bien, esta impunidad puede sortearse sin inconveniente alguno si se acoge el criterio de la accesoriedad mínima para castigar la participación y se adopta el esquema teórico derivado de la concepción significativa del delito. De este modo, se puede castigar, pues, penalmente al administrador de hecho que se vale del administrador de derecho; no ciertamente como autor, pero sí como partícipe. En suma, y recapitulando lo hasta aquí expuesto, cabe afirmar que para poder castigar al partícipe basta con que el autor haya realizado una acción que sea típicamente relevante y ofensiva para un bien jurídico penal, esto es, una acción en la que concurra la antijuridicidad material. En otras palabras, es suficiente con que el autor haya realizado una acción materialmente (u objetivamente) antijurídica, en la que concurre la predecibilidad general y la imputación objetiva, aunque se trate de una acción realizada sin infringir su norma de conducta (sin dolo ni imprudencia)".

39 MIR PUIG, S.: Derecho penal:..., ob. cit., 2004, pp. 398 y ss.: "En favor de la teoría de la accesoriedad limitada y en especial de la no dependencia del partícipe respecto de la posibilidad de imputación personal al autor, concurren diversos argumentos en el Código penal. Así, el significado de la palabra "hecho" (arts. 28 y $29 \mathrm{CP}$ ), empleada por la ley como presupuesto de las diferentes formas de participación, y que según se desprende de su uso en el art. $19 \mathrm{y}$ en los núms. $1^{\circ}, 2^{\circ}$ del art. $20 \mathrm{CP}$, no requiere la imputación personal al autor. [...] La doctrina dominante en Alemania exige el dolo en el autor para que sea posibilidad la participación en un hecho. Ello es 
En mi opinión dicha interpretación de la redacción del art. 29 del Código penal resulta posible, pero no obligada y tampoco aconsejable.

Así las cosas, debe recordarse que el art. 29 del Código penal se limita a señalar que: "Son cómplices los que, no hallándose comprendidos en el artículo anterior, cooperan a la ejecución del hecho con actos anteriores o simultáneos".

La afirmación de que el término "hecho" implica la realización de una conducta típicamente objetiva y subjetiva, además de antijurídica, puede resultar una opción valorativamente viable, pero no resulta desde luego la única interpretación posible, pues qué duda cabe de que el término "hecho" presenta múltiples acepciones.

Creo que en realidad existen buenas razones para interpretar dicho vocablo como mero sustrato material que se identificaría con la simple realización objetiva del tipo, y que en todo caso cabría extender a la ausencia de causas de justificación ${ }^{40}$.

En realidad, el empleo del término "hecho" desnudo de cualquier otra consideración o adjetivo, parece identificarse de un modo más evidente con el sustrato fáctico de la acción típica, pues tal y como señala VIVES no debe olvidarse que el elemento subjetivo no resulta idóneo para delimitar el contenido del

coherente con la no admisión de la distinción de autoría y participación en los delitos imprudentes: [...] Mas en nuestro país se admite la participación en hechos imprudentes, por lo que la solución del tema será más compleja. Habrá que distinguir entre participación dolosa y no dolosa en un hecho[...] La participación dolosa en un hecho requiere el dolo del autor principal [...] Ello es consecuencia de la inclusión del dolo en el tipo: sin dolo del autor no hay tipo de homicidio en el que participar dolosamente. [...] Según lo dicho más arriba, la participación dolosa en un hecho imprudente (el partícipe quiere el hecho principal y el autor no), no es punible como tal participación dolosa, pero cabrá sin duda castigar por participación en el delito imprudente o acudirá la autoría mediata.

40 DE OLIVEIRA MONTEIRO, L.: La autoría mediata en ..., ob. cit., p. 148: "la palabra "hecho", no implica necesariamente la referencia a una conducta típica y antijurídica, ni en el anterior ni el actual Código penal [...] Incluso puede ser entendido sin dificultad como mero sustrato fáctico. 
acto típico, pues parece aconsejable que dicha tarea se resuelva en los términos propuestos por WITTGENSTEIN, conforme al concreto significado que el hecho objetivo desarrollado presente en sociedad con arreglo a las concretas reglas semánticas que resulten de aplicación ${ }^{41}$.

Asimismo, desde una perspectiva valorativa, no exclusivamente político-criminal, me parece más aconsejable la interpretación que aquí se propone del término hecho.

41 VIVES ANTÓN, T.S.: Fundamentos del sistema penal, ob. cit., p. 219: "Tanto en la doctrina penal como en la filosofía de la acción podemos, si la exposición efectuada es, en líneas generales, correcta, estimar inviables las concepciones de la acción que realizan la distinción entre acciones y hechos a partir de que en aquellas (a través del acto de voluntad o mediante cualquier otro artificio psicológico) se manifiesta una interioridad sustantiva del sujeto (sea su espíritu o, más sencillamente su cerebro) de la que brota el significado. Al respecto, se ha mostrado tanto que el sentido no se proyecta de dentro a fuera (de la mente a la vida social), sino de fuera a dentro (de la vida social a la mente), cuanto que la finalidad subjetiva (o la personalidad o el Yo) resulta, muchas veces, insuficiente o inservible para delimitar el significado que atribuíamos a las acciones. Así parece que hay que abandonar la idea de la acción como un objeto de dos pisos (uno físico y otro mental) pues, ni parece correcta, ni sirve para alojar en su seno todas las clases de acciones, ni explica por qué muchas de ellas son consideradas como tales y no reducidas a simples acontecimientos".

Vid. MARTÍNEZ-BUJÁN PÉREZ, C.: "La concepción significativa de la acción de T.S. VIVES y sus correspondencias sistemáticas con las concepciones teleológico-funcionales del delito", en Anuario Da Facultade da Dereito da Universidade da Coruña, $\mathrm{n}^{\circ}$ 5, 2001, pp. 1078 y 1079: “...la concepción ontológica de la acción como algo que hay en el mundo, ha pasado a entenderse de una forma distinta: no como algo que los hombres hacen, sino como el significado de lo que hacen; no como un sustrato, sino como un sentido. En atención a todo ello, concluye VIVES que la determinación de si se está ante una acción -así como el tipo de acción ante el que se está -ya no se efectúa con parámetros psicofísicos, mediante el recurso a la experiencia externa e interna, sino que tiene lugar en términos de reglas, o sea, en términos normativos. [...] la acción ya no será un hecho específico ni podrá ser definida como sustrato de la imputación jurídico-penal; antes al contrario, las acciones serán interpretaciones que según los diferentes tipos de reglas sociales, podrán darse al comportamiento humano. 
Así las cosas, si convenimos en que el fundamento de lo injusto penal radica en la tutela de los bienes jurídicos, y de un modo coherente con lo anterior, que el fundamento de la punición del partícipe se encuentra en el favorecimiento que su actuar tiene en la lesión del bien jurídico ejecutada por el autor del delito, y no por lo tanto en la solidarización con lo injusto de aquel, creo que existen buenas razones para sostener que la punición del partícipe debe producirse con independencia de que el autor del delito haya ejecutado el delito de un modo subjetivamente típico ${ }^{42}$.

Debe subrayarse que si bien es cierto, tal y como ya tuvimos ocasión de analizar con anterioridad, que no parece posible afirmar que lo injusto del partícipe resulte totalmente independiente de lo injusto ejecutado por el autor del delito, no es menos cierto que el respeto por el principio de culpabilidad, y por ello de responsabilidad por el hecho propio, exigen conceder un cierto grado de autonomía al análisis de aquel injusto.

Es por ello, por lo que tomando como referencia que el fundamento de la punición del partícipe se halla en el favorecimiento a una lesión del bien jurídico protegido objetivamente imputable al autor, parecería lógico que el contenido de su injusto se limitara a valorar si la conducta por él desarrollada resulta objetivamente disvaliosa, en atención a su concreta significación delictiva e idoneidad para favorecer la lesión ejecutada por el autor del delito. En definitiva, el hecho de que la conducta del

42 FEIJOO SÁNCHEZ, B.J.: Una polémica doctrinal interminable ¿son típicas en el Derecho penal español la participación imprudente y la participación en el delito imprudente?, en Diario la Ley $n^{\circ}$ 4973, 2000: "la posición mantenida en este trabajo no significa que se considere típico todo favorecimiento causal de un delito objetivamente previsible ex ante. Pero los límites que establecer son límites objetivos o valorativos relacionados con la "teoría de la imputación objetiva" y que tienen que ver más con el fundamento de la participación en general y con la estrecha relación que existe entre el principio de accesoriedad y el principio de autorresponsabilidad que tiene su fundamento material en el principio de autonomía o autodeterminación, que con el hecho de que la participación sea dolosa o imprudente". 
autor resulte subjetivamente típica en nada puede decirse que afecte al concreto disvalor del comportamiento del partícipe.

El dolo y la imprudencia no debe olvidarse que constituyen elementos de carácter estrictamente personal, con que el legislador limita el grado de desvalor personal del acto que considera necesario para elevar la conducta a la categoría de típica, de ahí que no resulte ni necesaria ni aconsejable su comunicación al partícipe.

La solución contraria conduce a la paradójica afirmación de que dos comportamientos exactamente idénticos, tanto en lo que a su desvalor de acción como de resultado se refiere, deban recibir tratamientos dispares, con arreglo a la simple concurrencia o ausencia del elemento subjetivo de un tercero que ninguna incidencia en el personal desvalor del acto del partícipe tiene, extremo éste que no alcanzo a comprender pueda encontrar justificación alguna. Adviértase, a modo de ejemplo, que quien creyendo erróneamente que un sujeto se haya resuelto a acabar con la vida de otra persona le hace entrega de un veneno, quien en la creencia de tratarse de una broma lo aplica jocosamente a la víctima, ocasionándole por error la muerte debiera quedar, incomprensiblemente impune, mientras que para el caso de haber contado con el dolo del sujeto activo delito debiera responder como cooperador necesario.

Así también el Secretario municipal que tras ser compelido durante el transcurso del pleno municipal a pronunciarse sobre la licitud de la propuesta en materia de contratación administrativa sometida a votación por el Alcalde, informara favorablemente acerca del contenido de la propuesta, a pesar de su abierta contradicción con el ordenamiento jurídico, en la creencia de hallarse actuando en el modo deseado por el Alcalde con el fin de conducir a confusión al resto de miembros del órgano competente para el dictado de la resolución, debiera resultar absuelto, pues a diferencia de lo que sucede en el ámbito de la prevaricación urbanística y medioambiental, la mera emisión de informe contrario a la legalidad no constituye una modalidad 
típica en el ámbito de la prevaricación administrativa genérica del art. 404 del Código penal.

Tamaña diferencia en el tratamiento punitivo de una conducta exactamente idéntica en lo que a su desvalor de acción y resultado se refiere no me parece razonable, y desde luego tampoco deseada por el legislador. Pues adviértase, regresando al último de los ejemplos expuestos, que la conducta del Secretario que emite informe contrario a la legalidad con el fin de conducir a confusión a quienes deben resolver, logrando que de aquel modo dicten una resolución contraria al ordenamiento positivo, goza de idéntico desvalor de acción y de resultado con independencia de que el Alcalde obrara de un modo doloso o no lo hiciera. En ambos casos lo disvalioso de la acción del Secretario habría consistido en emitir a sabiendas un informe de modo torticero, mientras que lo disvalioso del resultado habría consistido en la creación de un error que a su vez habría provocado el dictado de una resolución arbitraria. Hacer depender el reproche penal del Secretario municipal de la concurrencia en un tercero, en este caso el Alcalde, de un determinado elemento subjetivo, resulta en mi opinión injustificado pues implicaría admitir que una conducta preñada de idéntico desvalor de acción y de resultado pudiera recibir un tratamiento jurídico-penal radicalmente opuesto en base al ánimo presente en un tercero.

\section{Bibliografía}

ALONSO PÉREZ, F.: Delitos cometidos por los funcionarios públicos en el nuevo Código Penal: legislación, comentarios, jurisprudencia, Ed. Dykinson, Madrid, 2002.

ASUA BATARRITA, A.: "La tutela penal del correcto funcionamiento de la Administración. Cuestiones político-criminales, criterios de interpretación y delimitación respecto a la potestad disciplinaria", en Varios autores, Delitos contra la Administración Pública, Instituto Vasco de Administración Pública, Bilbao, 1997. 
BACIGALUPO, E.: "Cuestiones de la autoría y la participación en el delito fiscal”, en Diario la Ley, no 8715, 2016.

BACIGALUPO, S.: Autoría y participación en delitos de infracción de deber, Marcial Pons, Barcelona, 2008.

CANTERO, J.C.: La responsabilidad penal de los funcionarios por delitos ambientales, Reus, Madrid, 2010.

CATALÁN SENDER, J.: Los delitos cometidos por autoridades y funcionarios públicos, Bayer, Barcelona, 1999.

DE OLIVEIRA MONTEIRO, L.: La autoría mediata en los delitos imprudentes, Tirant lo Blanch, 2013.

DÍAZ Y GARCÍA CONLLEDO, M.: "Autoría y participación", en Revista de Estudios Jurídicos de la Justicia, n 10 , 2008.

DOLZ LAGO, M.J.: El delito de tráfico de influencias ante la lucha contra la corrupción política en España, La Ley, Madrid, 2014.

FARALDO CABANA, P.: Ordenación del territorio, patrimonio histórico y medio en el Código penal y la legislación especial, Tirant lo Blanch, Valencia, 2011.

FEIJOO SÁNCHEZ, B.J.: "Una polémica doctrinal interminable ¿son típicas en el Derecho penal español la participación imprudente y la participación en el delito imprudente?", en Diario la Ley, no 4973, 2000.

GARCÍA ARÁN, M. (Directora): La delincuencia económica: Prevenir y sancionar, Tirant lo Blanch, Valencia, 2014.

GIMBERNAT ORDEIG, E.: Autor y cómplice en Derecho penal, Universidad de Madrid, 1966.

GÓMEZ MARTÍN, V.: Los delitos especiales, Edisofer, Madrid, 2006.

GONZÁLEZ CUSSAC, J.G.: El delito de prevaricación de autoridades y funcionarios públicos, Tirant lo Blanch, Valencia, 1997.

GÓRRIZ ROYO, E.: Los delitos de prevaricación urbanística, Tirant lo Blanch, Valencia 2004.

HAVA GARCÍA, E.: "Prevaricación de los funcionarios públicos", en ÁlVAREZ GARCÍA, F.J.: Tratado de Dere- 
cho Penal Español, Parte Especial, III. Delitos contra las Administraciones Públicas y de Justicia, Tirant lo Blanch, Valencia, 2013.

JAKOBS, G.: Dogmática de Derecho penal y la configuración normativa de la sociedad, Thomson Civitas, Madrid, 2004.

JAKOBS, G.: Sobre la normativización de la dogmática jurídico-penal, editorial Thomson-Civitas, Navarra, 2003.

MARTÍNEZ-BUJÁN PÉREZ, C.: Derecho penal económico y de la empresa: Parte General, Tirant lo Blanch, Valencia, 2016.

MARTÍNEZ-BUJÁN PÉREZ, C.: El contenido de la antijuridicidad (Un estudio a partir de la concepción significativa del delito), Tirant lo Blanch, Valencia, 2013.

MARTÍNEZ-BUJÁN PÉREZ, C.: "La concepción significativa de la acción de T.S. VIVES y sus correspondencias sistemáticas con las concepciones teleológico-funcionales del delito", en Anuario Da Facultade da Dereito da Universidade da Coruña, $\mathrm{n}^{\circ}$ 5, 2001.

MENA ÁlVAREZ, J.M.: De oficio Fiscal, Ariel, Barcelona, 2010.

MIR PUIG, S.: Derecho penal: parte general, Reppertor, Barcelona, 2004.

MUÑOZ CONDE, F./ GARCÍA ARÁN, M.: Derecho penal, Parte General, Tirant lo Blanch, Valencia, 2015.

PALOMAR OLMEDA. A./ GARCÉS SANAGUSTÍN, M.: La gestión de los Fondos Públicos: Control y Responsabilidades, Aranzadi, Navarra, 2013.

PEÑARANDA RAMOS, E.: La participación en el delito y el principio de accesoriedad, B de f, Buenos Aires, 2018.

QUINTERO OLIVARES, G.: Parte General del Derecho penal, Aranzadi, Navarra, 2010.

QUINTERO OLIVARES, G.: "Urbanismo y corrupción en la Administración local", en MORILLAS CUEVA, L.: Urbanismo y corrupción política, Dykinson, Madrid, 2013. 
SANZ-DÍEZ DE ULZURRUN, M.: Dolo e imprudencia en el Código penal español, Tirant lo Blanch, Valencia 2007. URQUIZA, J.M.: Corrupción Municipal. Por qué se produce y como evitarla, Almuzara, Córdoba, 2006.

VIDAL CASTAÑÓN, A.: “¿Argumentación o pretexto? A propósito de la fundamentación jurídica del Tribunal Supremo español para condenar a los partícipes en determinados casos donde no se castiga al autor del hecho principal”, en Diario La Ley, n 8321, 2014. 